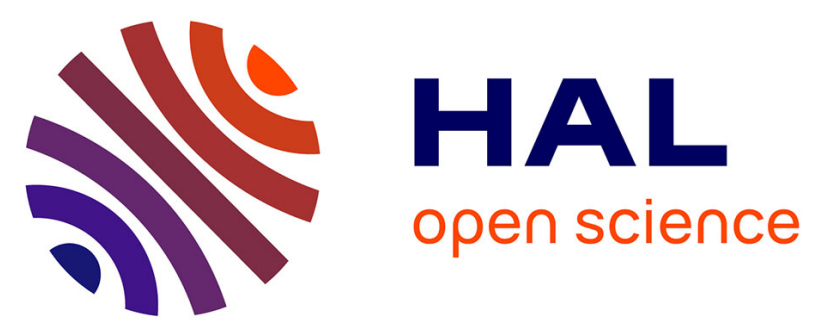

\title{
A Bispidol Chelator with a Phosphonate Pendant Arm: Synthesis, Cu(II) Complexation, and (64)Cu Labeling
} Raphaël Gillet, Amandine Roux, Jérémy Brandel, Sandrine Huclier-Markai, Franck Camerel, Olivier Jeannin, Aline M. Nonat, Loïc J. Charbonnière

\section{- To cite this version:}

Raphaël Gillet, Amandine Roux, Jérémy Brandel, Sandrine Huclier-Markai, Franck Camerel, et al.. A Bispidol Chelator with a Phosphonate Pendant Arm: Synthesis, $\mathrm{Cu}$ (II) Complexation, and (64)Cu Labeling. Inorganic Chemistry, 2017, 56 (19), pp.11738-11752. 10.1021/acs.inorgchem.7b01731 . hal-01617953

\section{HAL Id: hal-01617953 \\ https://hal-univ-rennes1.archives-ouvertes.fr/hal-01617953}

Submitted on 1 Dec 2017

HAL is a multi-disciplinary open access archive for the deposit and dissemination of scientific research documents, whether they are published or not. The documents may come from teaching and research institutions in France or abroad, or from public or private research centers.
L'archive ouverte pluridisciplinaire HAL, est destinée au dépôt et à la diffusion de documents scientifiques de niveau recherche, publiés ou non, émanant des établissements d'enseignement et de recherche français ou étrangers, des laboratoires publics ou privés. 


\section{Bispidol chelator with phosphonate pendant arm:}

\section{synthesis, $\mathrm{Cu}(\mathrm{II})$ complexation and ${ }^{64} \mathrm{Cu}$ labeling}

Raphaël Gillet,† Amandine Roux,† Jérémy Brandel,ł Sandrine Huclier-Markai,§ ¥ Franck

Camerel,ð Olivier Jeannin, ð Aline M. Nonat, *†, Loïc J. Charbonnière*†

†Laboratoire d’Ingénierie Moléculaire Appliquée à l’Analyse, Université de Strasbourg, CNRS, IPHC UMR 7178, F-67000 Strasbourg, France.

‡ Laboratoire de Reconnaissance et Procédés de Séparation Moléculaire, Université de

Strasbourg, CNRS, IPHC UMR 7178, F-67000 Strasbourg, France.

§ GIP Arronax, 1 rue Aronnax, CS 10112, F-44817 Saint-Herblain, France.

‡ Subatech Laboratory, UMR 6457, Ecole des Mines de Nantes, IN2P3/CNRS, Université de

Nantes, 4 rue Alfred Kastler, F-44307 Nantes, France.

$ð$ Laboratoire Matière Condensée et Systèmes Électroactifs, Institut des Sciences Chimiques de

Rennes, UMR-CNRS 6226, 263 Avenue du Général Leclerc, CS 74205, F-35042 Rennes Cedex,

France

aline.nonat@unistra.fr, 1.charbonn@unistra.fr

KEYWORDS : ${ }^{64} \mathrm{Cu}$ / selectivity / kinetic inertness / bispidine / phosphonate/ radiolabelling /

PET

ABSTRACT. Here we present the synthesis and characterization of a new bispidine $(3,7-$ diazabicyclo[3.3.1]nonane) ligand with $\mathrm{N}$-methanephosphonate substituents $\left(\mathbf{L}_{2}\right)$. Its physicochemical properties in water, as well as those of the corresponding $\mathrm{Cu}(\mathrm{II})$ and $\mathrm{Zn}$ (II) complexes, 
have been evaluated by using UV-visible absorption spectroscopy, potentiometry, ${ }^{1} \mathrm{H}$ and ${ }^{31} \mathrm{P}$ NMR and cyclic voltammetry. Radiolabelling experiments with ${ }^{64} \mathrm{Cu}(\mathrm{II})$ have been carried out, showing excellent radiolabelling properties. Quantitative complexation was achieved within 60 minutes under stoichiometric conditions, at room temperature and in the nanomolar concentration range. It was also demonstrated that the complexation occurred below $\mathrm{pH}=2$. Properties have been compared to those of the analogue bispidol bearing a $\mathrm{N}$ methanecarboxylate substituent $\left(\mathbf{L}_{1}\right)$. Although both systems meet the required criteria to be used as new chelator for ${ }^{64 / 67} \mathrm{Cu}$ in terms of formation kinetic, thermodynamic stability, selectivity for $\mathrm{Cu}(\mathrm{II})$, kinetic inertness regarding redox or acid-assisted decomplexation processes, substitution of the carboxylic acid function by the phosphonic moiety is responsible for a significant increase of the thermodynamic stability of the $\mathrm{Cu}(\mathrm{II})$ complex $(+2 \log$ units for $\mathrm{pCu})$ and also leads to an increase of the radiochemical yields with ${ }^{64} \mathrm{Cu}(\mathrm{II})$ which is quantitative for $\mathbf{L}_{2}$.

\section{Introduction}

Bispidine derivatives are highly preorganized ligands that can accommodate metal ions with cisoctahedral, square pyramidal or pentagonal geometries. ${ }^{1,2}$ They usually form thermodynamically very stable metal complexes with transition metal ions which often show high kinetic inertness. ${ }^{3,45}$ Modification of the coordinating pendant arms can be used to tune the ligand denticity as well as all electronic, thermodynamic and kinetic parameters such as the ligand field, the metal selectivity, the stability constants and the redox potentials. Such properties are very appealing for applications in catalysis, ${ }^{6,7,8,9,10,11,12}$ in molecular magnetism ${ }^{13,14,15,16,17}$ and in nuclear medicine and diagnosis as chelator for ${ }^{64 / 67} \mathrm{Cu} .{ }^{18,19,20,21}$ 
This study focuses on the use of two bispidine derivatives $\left(\mathbf{L}_{1}\right.$, and $\mathbf{L}_{2}$, Chart 1$)$ as chelators for radioactive copper for application in immuno-Positron Emission Tomography (PET) $\left({ }^{64} \mathrm{Cu}, t_{1 / 2}=\right.$ $\left.12.7 \mathrm{~h}, \beta^{+}, 17.8 \%, 653 \mathrm{keV}, \beta, 38.4 \%, 579 \mathrm{keV}\right) .{ }^{22}$ In this context, bifunctional chelators (BFCs) are needed, providing a strong chelating site for radioactive copper complexation as well as a reactive function for conjugation to a monoclonal antibody (mAb) (or a fragment) of interest. Lots of progresses in antibody technologies as well as site-specific conjugation methods ${ }^{23,24}$ have been made in the recent years and it is now within our grasp to find or design engineered $\mathrm{mAb}$ fragments for almost any molecular target. ${ }^{25}$ Radiolabeled antibodies have been introduced in clinical use $e^{26,27,28,29}$ and a large range of BFCs are now available. ${ }^{30,31,32}$ However, only a few chelators fulfill all of the very specific criteria which are required to radiolabel antibody-BFC conjugates in good conditions, i.e. (i) fast radiolabelling (a few minutes to one hour) at room temperature and around physiological pH; (ii) high in vivo stability and kinetic inertness towards transmetallation, transchelation and reduction; and (iii) easy access synthesis and bioconjugation..$^{33,34}$

Chart 1. Structure of acid functionalized ligands $\left(\mathbf{L}_{1}-\mathbf{L}_{2}\right)$ studied and the related bispidone $\left(\mathbf{L}_{3}\right)$. 


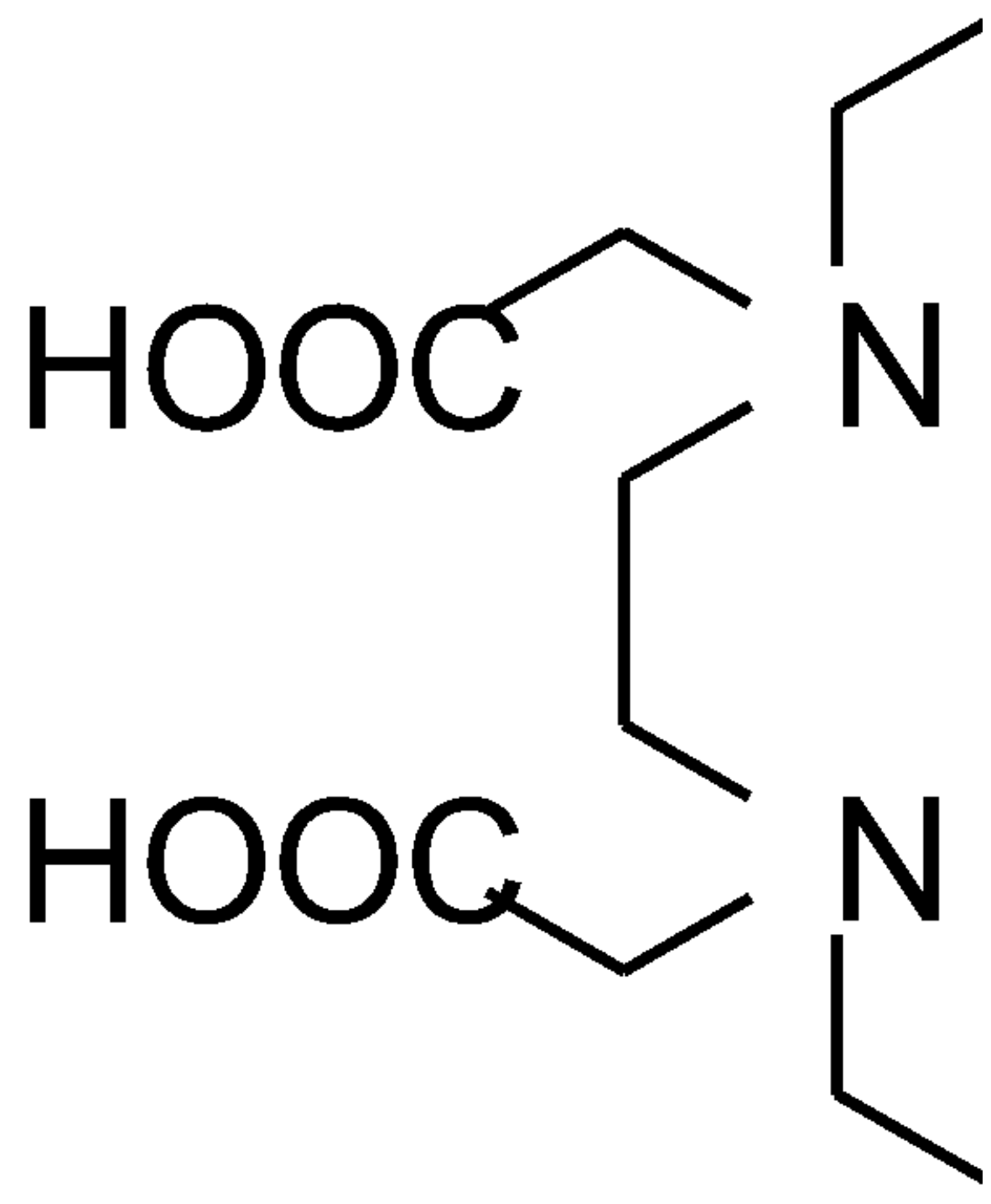

Chart 2. Structure of other ligands discussed in this work.

Three classes of ligands with polyaza donor sets are commonly used: macrocyclic, linear and macrobicyclic. NOTA ${ }^{35,36}$ and TETA ${ }^{37,38,39}$ and their derivatives are easily accessible but often 
suffer from low kinetic inertness. Variations of the substituent are being explored in order to improve the in vivo stability of the Cu complexes (see HTE1PA, ${ }^{40,41,42,43}$ NO1PA2PY $^{44}$ and its derivatives, ${ }^{45}$ Chart 2). Very stable and inert cyclen-based cross-bridged systems (such as PycupBn ${ }^{46}$ and CB-TE2A, ${ }^{47}$ Chart 2) and macrobicycles such as $\mathbf{L}_{7}{ }^{48}$ are being developed but their slow kinetic of complexation is hampering their use for the labeling of antibodies. Faster complexation is observed with N-phosphonic acid analogues, although heating is still necessary for the moment. ${ }^{49,50,51,52}$ New linear systems such as $\mathrm{H}_{2}$ DEDPA and H2AZAPA ${ }^{53,54}$ as well as other type of macrocyclic ligands and cages (DiamSar ${ }^{55,56,57}$ and its derivatives) offer good radiolabelling conditions at room temperature (Chart 2) and for some of them, a high degree of kinetic inertness. Bispidine derivatives ( $\mathbf{L}_{4}$ and $\mathbf{L}_{5}$, Chart 2) also form particularly stable $\mathrm{Cu}(\mathrm{II})$ complexes in vitro and in vivo. $\mathbf{L}_{4}$ and $\mathbf{L}_{5}$ could be radiolabeled with $>95 \%$ radiolabelling yields within a minute at room temperature. ${ }^{18,4}$ Non-optimized specific activities of less than 0.1 GBq/ $/ \mu \mathrm{mol}$ were used for $\mathbf{L}_{4}{ }^{18}$ and $\mathbf{L}_{5}{ }^{19}$ and a specific activity of $26 \mathrm{GBq} / \mu \mathrm{mol}$ was obtained for $\mathbf{L}_{6}$ after 90 min at $50^{\circ} \mathrm{C}^{20}$ Preliminary in vivo studies in mice and rats for $\mathbf{L}_{\mathbf{4}}$ and $\mathbf{L}_{6}$ indicated rapid blood and tissue clearance as well as the absence of demetallation. However, changes were observed over time in the radio-HPLC chromatogram of $\mathbf{L}_{\mathbf{4}}$, which were attributed to partial or total hydrolysis of the ester functions by the esterase in rat plasma. ${ }^{18}$ Dioxotetraaza macrocycles $\left(\mathbf{L}_{6}\right.$, Chart 2) are also very stable, although efficient labeling was observed only after heating the samples at $50^{\circ} \mathrm{C} \cdot{ }^{20}$

Our previous studies on the methylene carboxylate-substituted bispidine $\mathbf{L}_{\mathbf{1}}$, have shown that this ligand is another good candidate for PET applications. ${ }^{21}$ Fast complexation occurs even at low $\mathrm{pH}$ values $(\mathrm{pH}=1)$, with a high binding constant for $\mathrm{Cu}(\mathrm{II})$ versus competing metals (Co(II), $\mathrm{Ni}(\mathrm{II}), \mathrm{Zn}(\mathrm{II}))$ and the complex is characterized by a strong stability in acidic medium $\left(t_{1 / 2}=\right.$ 
110 days at $\left.25^{\circ} \mathrm{C}, 5 \mathrm{M} \mathrm{HClO}_{4}\right)$ and upon reduction $\left(E_{1 / 2}=-430 \mathrm{mV}\right.$ vs $\left.\mathrm{NHE}\right)$. Radiolabelling with ${ }^{64} \mathrm{CuCl}_{2}$ is fast $(<5 \mathrm{~min})$ and easily performed at room temperature and at micromolar concentrations of $\mathbf{L}_{1}$ in water $(4 \leq \mathrm{pH} \leq 6) .{ }^{58}$ In these conditions, $\geq 90 \%$ radiolabeling yields were obtained. Moreover, the risk of enzymatic degradation is suppressed since the ester functions have been hydrolyzed prior complexation. In this study, we report the synthesis and physicochemical evaluation and the radiolabelling studies of a new methane phosphonate analogue $\mathbf{L}_{2}$ in water. Substitution of the acetic acid pendant arm by a methanephosphonic acid moiety was expected to improve the ligand selectivity for $\mathrm{Cu}(\mathrm{II})$ and to increase the thermodynamic and kinetic stability of the complex. This expectation is corroborated by literature data on phosphonate pendant-armed tetraazamacrocyclic chelators such as PCBTEA1P $\mathrm{P}^{51,59}$ as well as on the podal pyridine derivatives developed in our group, $\mathrm{L}_{8}$ (Chart 2). $60,61,62$

\begin{tabular}{|c|c|c|c|c|}
\hline & Radiolabelling conditions & $\mathbf{t}_{1 / 2}$ & $\mathbf{p C \mathbf { u } ^ { \mathrm { a } }}$ & $\mathbf{E}_{\text {red }}(\mathbf{m V} v s \mathrm{NHE})$ \\
\hline TETA $^{31,32}$ & $25^{\circ} \mathrm{C}, 60 \mathrm{~min}, \mathrm{pH}$ 5-7 & $3.5 \mathrm{~d}\left(5 \mathrm{M} \mathrm{HCl}, 30^{\circ} \mathrm{C}\right)$ & 15.1 & -980 (irrev) \\
\hline CB-TE2A ${ }^{51}$ & $95^{\circ} \mathrm{C}, 60 \mathrm{~min}, \mathrm{pH} \mathrm{6-7}$ & $154 \mathrm{~h}\left(5 \mathrm{M} \mathrm{HCl}, 90^{\circ} \mathrm{C}\right)$ & - & $-880\left(E_{1 / 2}\right)$ \\
\hline HTE1PA $^{40,41}$ & r.t., 15 min, pH 5 & $\begin{array}{l}32 \min \left(\mathrm{HCl} 1 \mathrm{M}, 25^{\circ} \mathrm{C}\right) \\
144 \min \left(5 \mathrm{M} \mathrm{HClO} 4,25^{\circ} \mathrm{C}\right)\end{array}$ & 18.64 & - \\
\hline CB-TE1PA ${ }^{94}$ & - & $96 \mathrm{~d}\left(5 \mathrm{M} \mathrm{HClO} 4,25^{\circ} \mathrm{C}\right)$ & 16.6 & $-620\left(E_{1 / 2}\right)$ \\
\hline PCTA $^{63,35}$ & $25^{\circ} \mathrm{C}, 5 \mathrm{~min}, \mathrm{pH} 5.5$ & - & 19.1 & - \\
\hline DiamSar $^{55,56,57}$ & $25^{\circ} \mathrm{C}, 5-30 \mathrm{~min}, \mathrm{pH} 5.5$ & $40 \mathrm{~h}\left(5 \mathrm{M} \mathrm{HCl}, 90^{\circ} \mathrm{C}\right)$ & - & -900 (irrev) \\
\hline NOTA $^{30,64,32}$ & $\begin{array}{l}25^{\circ} \mathrm{C}, 30-60 \mathrm{~min}, \mathrm{pH} 5.5- \\
6.5\end{array}$ & $<3 \min \left(5 \mathrm{M} \mathrm{HCl}, 30^{\circ} \mathrm{C}\right)$ & 18.4 & -700 (irrev) \\
\hline NO1PA2PY $^{44}$ & r.t., $30 \mathrm{~min}, \mathrm{pH}$ 6-7 & $204 \min \left(3 \mathrm{M}, \mathrm{HCl}, 90^{\circ} \mathrm{C}\right)$ & 17.75 & -518 \\
\hline H2DEDPA $^{53}$ & $25^{\circ} \mathrm{C}, 5-10 \mathrm{~min}, \mathrm{pH} 5.5$ & $<5 \min \left(6 \mathrm{M} \mathrm{HCl}, 90^{\circ} \mathrm{C}\right)$ & 18.5 & -920 (irrev) \\
\hline H2AZAPA $^{65}$ & $25^{\circ} \mathrm{C}, 5-10 \mathrm{~min}, \mathrm{pH} 5.5$ & - & - & - \\
\hline
\end{tabular}




\begin{tabular}{|c|c|c|c|c|}
\hline $\mathbf{L}_{1}^{\mathrm{b}, 21}$ & r.t., 15 min, pH 2-6 & $110 \mathrm{~d}\left(5 \mathrm{M} \mathrm{HClO}_{4}, 25^{\circ} \mathrm{C}\right)$ & 17.0 & -560 \\
\hline $\mathbf{L}_{2}^{\mathrm{b}}$ & r.t., 5-15 min, pH 3-6.6 & $\begin{array}{l}>20 \text { months (5M } \mathrm{HClO}_{4} \text {, } \\
\left.25^{\circ} \mathrm{C}\right)\end{array}$ & 19.1 & -600 \\
\hline $\mathbf{L}_{4}{ }^{18,4}$ & r.t., 1 min, pH 6.5 & & 16.28 & -303 \\
\hline $\mathbf{L}_{5}{ }^{19}$ & r.t., 1 min, pH 5.5 & - & - & - \\
\hline $\mathbf{L}_{6}{ }^{20}$ & $50^{\circ} \mathrm{C}, 60 \mathrm{~min}, \mathrm{pH} 6.5$ & - & - & - \\
\hline PCB-TEA1P ${ }^{51}$ & $60^{\circ} \mathrm{C}, 1 \mathrm{~h}, \mathrm{pH} 8$ & $8 \mathrm{~d}\left(12 \mathrm{M} \mathrm{HCl}, 90^{\circ} \mathrm{C}\right)$ & - & -573 \\
\hline $\mathbf{L}_{7}^{60,62}$ & - & - & 15.5 & - \\
\hline
\end{tabular}

${ }^{\mathrm{a}} \mathrm{pCu}=-\log \left[\mathrm{Cu}(\mathrm{II})_{\text {free }}\right],[\mathrm{Cu}]=10^{-6} \mathrm{M},[\mathrm{L}]=10^{-5} \mathrm{M}, \mathrm{pH}=7.4$

${ }^{\mathrm{b}}$ This work.

Table 1. Radiolabelling conditions (at r.t.), half life $\left(\mathrm{t}_{1 / 2}\right), \mathrm{pCu}$ and reduction potential $\left(\mathrm{E}_{\mathrm{red}}\right)$ for a selection of ligands.

General Methods. Solvents and starting materials were purchased from Aldrich, Acros and Alfa Aesar and used without further purification. IR spectra were recorded on a Perkin Elmer Spectrum One Spectrophotometer as solid samples and only the most significant absorption bands are given in $\mathrm{cm}^{-1}$. Elemental analyses and mass spectrometry analysis were carried out by the Service Commun d'Analyses of the University of Strasbourg. ${ }^{1} \mathrm{H}$ and ${ }^{13} \mathrm{C}$ NMR spectra and 2D COSY, NOESY, HSQC, and HMBC experiments were recorded on Bruker Avance 300 and Avance 400 spectrometers operating at 300 and $400 \mathrm{MHz}$, respectively. Chemical shifts are reported in ppm, relative to residual protonated solvent as internal reference. ${ }^{66}$ The $\mathrm{pH}$ values given are corrected for the deuterium isotopic effects. ${ }^{67}$ Elemental analysis and monoisotopic masses were calculated with the chemcalc software. ${ }^{68}$

X-ray Crystallography. Crystals of the intermediate 2 (Scheme 1) and $\mathbf{L}_{2}$ ligand suitable for Xray diffraction were obtained by slow evaporation of methanol solutions. The crystals were placed in oil, and a single crystal was selected, mounted on a nylon loop and placed in a low- 
temperature $\mathrm{N}_{2}$ stream. X-Ray diffraction data collection was carried out on a Bruker APEX II Kappa-CCD diffractometer equipped with an Oxford Cryosystem liquid $\mathrm{N}_{2}$ device, using Mo-Ka radiation $(\lambda=0.71073 \AA)$ at $150(2) \mathrm{K}$ (Centre de diffractométrie X, Université de Rennes 1, France). Bruker SMART program were used to refine the values of the cell parameters. Data reduction and correction for absorption (SADABS) were carried out using the Bruker SAINT programs. The structures were solved by direct methods using the SIR97 program, ${ }^{69}$ and then refined with full-matrix least-square methods based on $F^{2}$ (SHELX-97) ${ }^{70}$ with the aid of the WINGX program. ${ }^{71}$ All non-hydrogen atoms were refined with anisotropic atomic displacement parameters.

For $\mathbf{2}$, all $\mathrm{H}$ atoms were included in their calculated positions, whereas, for $\mathbf{L}_{2}, \mathrm{H}$ atoms carried by heteroatoms were refined with isotropic atomic displacement parameters. Crystallographic data for structural analysis of $\mathbf{2}$ and $\mathbf{L}_{2}$ ligand have been deposited with the Cambridge Crystallographic Data Centre under CCDC N 1530206 and 1530205, respectively. Copies of this information may be obtained free of charge from the web site www.ccdc.cam.ac.uk.

Synthesis of the ligands. Piperidinone dimethyl-1-methyl-4-oxo-2,6-di(pyridin-2-yl)piperidine3,5-dicarboxylate $\left(\mathbf{P}_{\mathbf{1}}\right)$ was synthesized according to previously reported procedure. ${ }^{72}$

(aminomethyl)phosphonic acid $\mathbf{1}$. $\mathbf{1}$ was obtained in three steps from diethyl phosphate according to the Kabachnik-Fields reaction, according to an adaptation of the procedure used in reference. ${ }^{73}$ (i) To a solution of diethylphosphite (3.27 mL, 94\%, $20.7 \mathrm{mmol}, 1.2 \mathrm{eq}$ ) in THF (9 mL) were successively added dibenzylamine (3.39 mL, 98\%, $17.27 \mathrm{mmol}, 1 \mathrm{eq}$ ) and formaldehyde (3.06 $\mathrm{mL}, 37 \%$ in water, $34.5 \mathrm{mmol}$, 2eq). The mixture was heated at $60^{\circ} \mathrm{C}$ under stirring for $24 \mathrm{~h}$ and the reaction was monitored by TLC. After completion of the reaction, the mixture was taken to 
dryness under vacuum and the as-obtained yellow oil was dissolved in cyclohexane $(60 \mathrm{~mL})$ and washed with water $(3 \times 15 \mathrm{~mL})$. Diethyl((dibenzylamino)methyl)phosphonate was obtained as a colorless oil after evaporation of the cyclohexane under reduced pressure (6 g, quantitative). ${ }^{1} \mathrm{H}$ NMR (400 MHz, $\left.\mathrm{CDCl}_{3}\right): \delta 1.19\left(\mathrm{t}, J=7.1 \mathrm{~Hz}, 6 \mathrm{H}, \mathrm{CH}_{2} \mathrm{CH}_{3}\right), 2.77\left(\mathrm{~d}, J=10.5 \mathrm{~Hz}, 2 \mathrm{H}, \mathrm{NCH}_{2} \mathrm{P}\right)$, $3.67\left(\mathrm{~s}, 4 \mathrm{H}, \mathrm{NCH}_{2} \Phi\right)$ ), 3.95 (qd, $J_{1}=7.1 \mathrm{~Hz}, J_{2}=7.5 \mathrm{~Hz}, 4 \mathrm{H}, \mathrm{CH}_{2} \mathrm{CH}_{3}$ ), 7.11-7.28 (m, 10H, $\left.\Phi\right)$. ${ }^{31} \mathrm{P}$ NMR $\left(162 \mathrm{MHz}, \mathrm{CDCl}_{3}\right): \delta=25.7$.

(ii) Palladium over charcoal $(10 \%, 600 \mathrm{mg})$ was added to a solution of diethyl((dibenzylamino)methyl)phosphonate $(6 \mathrm{~g}, 17.27 \mathrm{mmol})$ in EtOH $(300 \mathrm{~mL})$ and the mixture was refluxed under a flow of hydrogen for $24 \mathrm{~h}$. The crude mixture was filtrated on a sintered-glass filter funnel filled with celite and the solvent was removed under vacuum to yield diethyl(aminomethyl)phosphonate (4.8 g, quantitative). ${ }^{1} \mathrm{H}$ NMR (400 MHz, $\left.\mathrm{CDCl}_{3}\right): \delta 1.25$ (t, $\left.J=6.7 \mathrm{~Hz}, 6 \mathrm{H}, \mathrm{CH}_{2} \mathrm{CH}_{3}\right), 1.97\left(\mathrm{~s}, 2 \mathrm{H}, \mathrm{NH}_{2}\right), 2.94\left(\mathrm{~d}, J=10.2 \mathrm{~Hz}, 2 \mathrm{H}, \mathrm{NCH}_{2} \mathrm{P}\right), 4.05(\mathrm{~m}, 4 \mathrm{H}$, $\left.\mathrm{CH}_{2} \mathrm{CH}_{3}\right) .{ }^{31} \mathrm{P}$ NMR (162 MHz, $\left.\mathrm{CDCl}_{3}\right): \delta 27.35 \mathrm{ppm}\left(\mathrm{qd}, J_{1}=8.5 \mathrm{~Hz}, J_{2}=9.2 \mathrm{~Hz}\right.$ ).

(iii) diethyl(aminomethyl)phosphonate $(4.81 \mathrm{~g}, 28.8 \mathrm{mmol})$ was dissolved in 6M hydrochloric acid (300 mL) and the mixture was refluxed for $16 \mathrm{~h}$ under stirring. After evaporation to dryness under reduced pressure, (aminomethyl)phosphonic acid $\mathbf{1}$ was obtained as a white powder (4.25 g, quantitative). ${ }^{1} \mathrm{H}$ NMR $\left(400 \mathrm{MHz}, \mathrm{CDCl}_{3}\right): \delta 3.00(\mathrm{~d}, \mathrm{~J}=13.0 \mathrm{~Hz}, 2 \mathrm{H}) .{ }^{31} \mathrm{P}$ NMR $(162 \mathrm{MHz}$, $\left.\mathrm{CDCl}_{3}\right): \delta 12.18 \mathrm{ppm}$.

Bispidone 2. (aminomethyl)phosphonic acid 1 (126 mg, $1.13 \mathrm{mmol}, 1.1 \mathrm{eq}$ ) was dissolved in a $\mathrm{H}_{2} \mathrm{O} / \mathrm{MeOH}(3 / 7)$ mixture $(11 \mathrm{ml})$ and stirred at room temperature in the presence of sodium hydrogenocarbonate (143 mg, $1.7 \mathrm{mmol}, 1.7$ eq). Piperidone $\mathbf{P}_{\mathbf{1}}$ (396 mg, $1.0 \mathrm{mmol}, 1 \mathrm{eq}$ ) in $8 \mathrm{ml}$ of $\mathrm{MeOH}$, was then added as well as formaldehyde $(93.0 \mathrm{mg}, 3.1 \mathrm{mmol}, 3 \mathrm{eq}, 0.23 \mathrm{ml}, 37 \%$ solution in $\mathrm{H}_{2} \mathrm{O}$ ). The reaction mixture was heated to $60^{\circ} \mathrm{C}$ for $5 \mathrm{~h}$, the reaction being monitored 
by TLC on (eluent: DCM/MeOH 9/1, $\mathrm{R}_{f}=0.26$ ). After completion of the reaction, the solvent was evaporated under reduced pressure and the crude product was suspended into EtOH (10 $\mathrm{mL}$ ). Bispidone 2 was isolated by centrifugation as a white powder (187 mg, $35 \%$ ). ${ }^{1} \mathrm{H}$ NMR (400 MHz, $\mathrm{CD}_{3} \mathrm{OD}$ ): $\delta 1.87$ (s, 3H, H3), 2.53 (d, $J=13.0 \mathrm{~Hz}, 2 \mathrm{H}, \mathrm{He}$ ), 3.15 (AB system, $\delta_{\mathrm{A}}=$ 2.66, $\left.\delta_{\mathrm{B}}=3.64, J_{A B}=12.3 \mathrm{~Hz}, 4 \mathrm{H}, \mathrm{H6} / \mathrm{H} 8\right), 3.72\left(\mathrm{~s}, 6 \mathrm{H}, \mathrm{OCH}_{3}\right), 4.68$ (s, $\left.2 \mathrm{H}, \mathrm{H} 2 / \mathrm{H} 4\right), 7.35$ (m, 2H, Hd), 7.42 (ddd, $\left.J_{1}=7.7 \mathrm{~Hz}, J_{2}=4.9 \mathrm{~Hz}, J_{3}=0.9 \mathrm{~Hz}, 2 \mathrm{H}, \mathrm{Hb}\right), 7.84$ (td, $J_{1}=7.8 \mathrm{~Hz}$, $J_{2}=1.5 \mathrm{~Hz}, 2 \mathrm{H}, \mathrm{Hc}$ ), 8.83 (dd, 2H, Ha). ${ }^{31} \mathrm{P}$ NMR (162 MHz, CD $\mathrm{OD}$ ): $\delta 15.29 \mathrm{ppm} .{ }^{13} \mathrm{C}$ NMR (100 MHz, $\mathrm{CD}_{3} \mathrm{OD}$ ): $\delta 41.9\left(\mathrm{CH}_{3}\right.$ ), 51.7 (2C, $\mathrm{OCH}_{3}$ ), 57.2 (d, Ce), 60.9 (2C, C6), 63.0 (2C, $\mathrm{C} 1$ ), 72.4 (2C, C2), 123.8 (2C, Cb), 124.7 (2C, Cd), 137.6 (2C, Cc), 150.6 (2C, Ca), 156.3 (2C, Сpy), 167.5 (2C, $\left.\mathrm{CO}_{2} \mathrm{Me}\right), 202.3$ (C9). Electrospray ionization (ESI) $/ \mathrm{MS}^{+}\left(\mathrm{CH}_{3} \mathrm{OH}\right): \mathrm{m} / \mathrm{z}=519.17$ $\left([\mathrm{M}+\mathrm{H}]^{+}, 100 \%\right)$. Anal. Calcd for $\mathrm{C}_{23} \mathrm{H}_{26} \mathrm{~N}_{4} \mathrm{O}_{8} \mathrm{PNa} \cdot 0.5 \mathrm{H}_{2} \mathrm{O}, \mathrm{C}, 50.28, \mathrm{H}, 4.95, \mathrm{~N}, 10.20$. Found: C, 50.39, H, 4.75, N, 10.27 .

Bispidol 3. Compound 2 (1.2 g, $2.3 \mathrm{mmol}, 1$ eq) was dissolved in $80 \mathrm{~mL}$ of anhydrous $\mathrm{MeOH}$ by heating and using ultrasound. The solution was then cooled to $-78^{\circ} \mathrm{C}$ and sodium borohydride (107 mg, $2.8 \mathrm{mmol}, 1.5$ eq) was gradually added. The reaction was monitored by TLC on C18 (eluent: $\mathrm{H}_{2} \mathrm{O} / \mathrm{ACN} 7 / 3, \mathrm{R}_{f}=0.28$ ). After $5 \mathrm{~h} 30$, the reaction was quenched at $-78^{\circ} \mathrm{C}$ by the addition of a saturated $\mathrm{NH}_{4} \mathrm{Cl}$ aqueous solution $(5 \mathrm{~mL})$. The solvent was evaporated under vacuum and the crude product was purified by FPLC on a C18 reverse phase column (eluent system: $\mathrm{H}_{2} \mathrm{O} / \mathrm{ACN} 0.1 \%$ TFA), giving the bispidol 3 (0.79 g, $66 \%$ ). ${ }^{1} \mathrm{H}$ NMR (400 MHz, $\mathrm{CD}_{3} \mathrm{OD}$ ): $\delta 1.74$ (s, 3H, H3), 3.35 (d, $J=11 \mathrm{~Hz}, 2 \mathrm{H}, \mathrm{He}$ ), 3.62 (s, 6H, $\left.\mathrm{OCH}_{3}\right), 4.0$ (AB system, $\delta_{\mathrm{A}}$ = 3.76, H6/8ax, $\delta_{\mathrm{B}}=4.23, \mathrm{H6} / 8 \mathrm{eq}, J=12.7 \mathrm{~Hz}, 4 \mathrm{H}$ ), 4.55 (s, 1H, H9), 4.98 (s, 2H, H2/H4), 7.43 (dd, $\left.J_{1}=7.0 \mathrm{~Hz}, J_{2}=5.2 \mathrm{~Hz}, 2 \mathrm{H}, \mathrm{Hb}\right), 7.65$ (d, $J=7.6 \mathrm{~Hz}, 2 \mathrm{H}, \mathrm{Hd}$ ), 7.87 (td, $J_{t}=7.7 \mathrm{~Hz}$, $\left.J_{d}=1.6 \mathrm{~Hz}, 2 \mathrm{H}, \mathrm{Hc}\right), 8.74$ (d, $\left.J=4.1 \mathrm{~Hz}, 2 \mathrm{H}, \mathrm{Ha}\right) .{ }^{31} \mathrm{P} \mathrm{NMR}\left(162 \mathrm{MHz}, \mathrm{CD}_{3} \mathrm{OD}\right): \delta 8.24 \mathrm{ppm}$. 
${ }^{13} \mathrm{C}$ NMR (100 MHz, CD ${ }_{3} \mathrm{OD}$ ): $\delta 40.7\left(\mathrm{CH}_{3}\right), 51.2$ (2C, C1), 51.8 (2C, $\left.\mathrm{OCH}_{3}\right), 53.2(\mathrm{~d}, J=133.9$ Hz, Ce), 55.8 (2C, C6), 66.2 (2C, C2), 71.9 (C9), 123.9 (2C, Cb), 127.6 (2C, Cd), 137.4 (2C, Cc), 149.3 (2C, Ca), 155.5 (2C, Cpy ), 168.7 (2C, $\mathrm{CO}_{2} \mathrm{Me}$ ). Electrospray ionization (ESI) / $\mathrm{MS}^{+}$ $\left(\mathrm{CH}_{3} \mathrm{OH}\right): \mathrm{m} / \mathrm{z}=521.18\left([\mathrm{M}+\mathrm{H}]^{+}, 100 \%\right)$. Anal. Calcd for $\mathrm{C}_{23} \mathrm{H}_{29} \mathrm{~N}_{4} \mathrm{O}_{8} \mathrm{P} \cdot 0.5 \mathrm{H}_{2} \mathrm{O}, \mathrm{C}, 52.17, \mathrm{H}$, 5.71, N, 10.58. Found: C, 51.94, H, 5.56, N, 10.41.

Ligand $\boldsymbol{L}_{2}$. Compound 3 (514 mg, 1 mmol, 1 eq) was dissolved in a THF/ $\mathrm{H}_{2} \mathrm{O}$ (1:1) mixture (30 $\mathrm{mL}$ ) and a solution of sodium hydroxide (200 mg, $5 \mathrm{mmol}, 5 \mathrm{eq}$ ) in water ( $5 \mathrm{~mL}$ ) was added. The mixture was stirred at room temperature and the reaction was monitored by TLC (eluent system: $\left.\mathrm{H}_{2} \mathrm{O} / \mathrm{ACN} 8: 2,0.1 \% \mathrm{TFA}, \mathrm{R} f=0.65\right)$. After completion of the reaction, the mixture was evaporated to dryness, redissolved in $1 \mathrm{M}$ hydrochloric acid and purified by flash chromatography with a C18 reverse phase column (eluent system: $\mathrm{H}_{2} \mathrm{O} / \mathrm{ACN} 0.1 \%$ TFA), to give ligand $\mathbf{L}_{2} \cdot \mathrm{NaCl} \cdot 4 \mathrm{H}_{2} \mathrm{O}\left(621 \mathrm{mg}\right.$, quantitative). ${ }^{1} \mathrm{H} \mathrm{NMR}\left(300 \mathrm{MHz}, \mathrm{CD}_{3} \mathrm{OD}\right): \delta 1.78(\mathrm{~s}, 3 \mathrm{H}$, $\mathrm{NCH}_{3}$ ), 2.34 (d, $J=12.2 \mathrm{~Hz}, 2 \mathrm{H}, \mathrm{He}$ ), 2.67 (AB system, $\delta_{\mathrm{A}}=2.09, \mathrm{H6} / 8 \mathrm{ax}, \delta_{\mathrm{B}}=3.24, \mathrm{H6} / 8 \mathrm{eq}$, $J_{A B}=12.4 \mathrm{~Hz}, 4 \mathrm{H}$ ), 3.88 (s, 1H, H9), 4.61 (s, 2H, H2/H4), 7.24 (m, 2H, Hb); 7.47 (d, J = 7.6 Hz, 2H, Hd), 7.65 (t, $J=7.3 \mathrm{~Hz}, \mathrm{Hc}$ ), 8.76 (d, $J=3.7 \mathrm{~Hz}, 2 \mathrm{H}, \mathrm{Ha}) .{ }^{31} \mathrm{P}$ NMR (162 MHz, $\left.\mathrm{CD}_{3} \mathrm{OD}\right): \delta$ $16.28 \mathrm{ppm}(\mathrm{t}, J=12.0 \mathrm{~Hz}) \cdot{ }^{13} \mathrm{C}$ NMR (100 MHz, $\left.\mathrm{CD}_{3} \mathrm{OD}\right): \delta 42.9\left(\mathrm{CH}_{3}\right), 51.7$ (2C, C1), 59.2 (2C, C6), 60.5 (d, J = 145.7 Hz, C9), 68.3 (2C, C2), 74.8 (C9), 122.0 (Cb), 125.7 (Cd), 136.1 (Cc), 149.5 (Ca), 160.62 (2C, Cpy), 178.34 (2C, $\left.\mathrm{CO}_{2} \mathrm{H}\right)$. Electrospray ionization (ESI) / $\mathrm{MS}^{+}$ $\left.\left(\mathrm{CH}_{3} \mathrm{OH}\right): \mathrm{m} / \mathrm{z}=493.15[\mathrm{M}+\mathrm{H}]^{+}, 100 \%\right)$. Anal. Calcd for $\mathrm{C}_{21} \mathrm{H}_{25} \mathrm{~N}_{4} \mathrm{O}_{8} \mathrm{P} \cdot \mathrm{NaCl} \cdot 4 \mathrm{H}_{2} \mathrm{O}, \mathrm{C}, 40.49, \mathrm{H}$, 5.34, N, 8.99. Found: C, 40.32, H, 5.03, N, 8.92. 


\section{Physico-chemical studies.}

Materials. Distilled water was purified by passing through a mixed bed of ion-exchanger (Bioblock Scientific R3-83002, M3-83006) and activated carbon (Bioblock Scientific ORC83005). All the stock solutions were prepared by weighing solid products using an AG 245 Mettler Toledo analytical balance (precision $0.01 \mathrm{mg}$ ). Metal cation solutions were prepared from their perchlorate salts $\left(\mathrm{Cu}\left(\mathrm{ClO}_{4}\right)_{2} \cdot 6 \mathrm{H}_{2} \mathrm{O}, 98 \%\right.$, Fluka; $\mathrm{Zn}\left(\mathrm{ClO}_{4}\right)_{2} \cdot 6 \mathrm{H}_{2} \mathrm{O}, 98.9 \%$, Alfa Aesar) and their concentrations were determined by colorimetric titrations with EDTA $\left(10^{-2} \mathrm{M}\right.$, Merck,

Titriplex III) according to standard procedures. ${ }^{74}$ Sodium hydroxyde $(\mathrm{NaOH})$ and hydrochloric acid ( $\mathrm{HCl}$ ) were used to adjust $\mathrm{pH}$ during titrations. The ionic strength of all the solutions was fixed to $0.1 \mathrm{M}$ with potassium chloride (KCl, Fluka, 99.0\%). All the experiments described were repeated at least three times.

CAUTION! Perchlorate salts combined with organic ligands are potentially explosive and should be handled in small quantities and with the adequate precautions. ${ }^{75}$

Potentiometry. The protonated species of $\mathbf{L}_{2}$ and the stability constants of $\mathbf{L}_{2}$ complexes with $\mathrm{Cu}(\mathrm{II})$ and $\mathrm{Zn}(\mathrm{II})$ complexes were characterized and quantified by potentiometric titrations in water. All the solutions used in the potentiometric experiments were prepared from boiled and degassed water. Titrations were performed using an automated titrating system (DMS 716 Titrino, Metrohm) with a combined glass electrode (Metrohm, 6.0234.100, Long Life) filled with $\mathrm{NaCl} 0.1 \mathrm{M}$. The electrode was calibrated as a hydrogen concentration probe by titrating known amounts of hydrochloric acid with $\mathrm{CO}_{3}{ }^{2-}$ free potassium hydroxide solutions. The GLEE program $^{76,77}$ was used for the glass electrode calibration. 
In a typical experiment, an aliquot of $10 \mathrm{~mL}$ of $\mathbf{L}_{2}\left(2 \cdot 10^{-3} \mathrm{M}\right)$ or $\mathbf{M}: \mathbf{L}_{2}(\mathrm{M}=\mathrm{Cu}(\mathrm{II})$ or $\mathrm{Zn}(\mathrm{II})$, [M]/ $[\mathbf{L}] \approx 1)$ was introduced into a thermostated jacketed cell $\left(25.0(2){ }^{\circ} \mathrm{C}\right.$, Metrohm) and kept under argon during the titrations. The solutions were acidified with a known volume of $\mathrm{HCl}$ and the titrations were then carried out by addition of known volumes of potassium hydroxide solution over the $\mathrm{pH}$ range 2-12. The potentiometric data of $\mathbf{L}_{2}$ and its metal complexes were refined with the Hyperquad 2008 program ${ }^{78}$ which uses non-linear least-squares methods, taking into account the formation of metal hydroxide species. The titration of each system was repeated at least in duplicate and the sets of data for each system were treated independently, then merged together and treated simultaneously to give the final stability constants. The distribution curves as a function of $\mathrm{pH}$ of the protonated species of $\mathbf{L}_{2}$ and of $\mathbf{L}_{2}$ metal complexes were calculated using the Hyss2009 program. $^{79}$

Spectrophotometry. The protonation constants of $\mathbf{L}_{2}$ and the stability constants of $\mathbf{M}: \mathbf{L}_{2}$ $\left(\mathrm{M}=\mathrm{Cu}(\mathrm{II})\right.$ and $\left.\mathrm{Zn}(\mathrm{II})[\mathrm{M}] /[\mathbf{L}] \sim 1,[\mathbf{L}] \sim 5.10^{-5} \mathrm{M}\right)$ were also determined by UV-Visible spectrophotometric titration versus $\mathrm{pH}$. Since complexation started in very acidic medium, the titrations were carried out in two different ways. Between $\mathrm{pH}=-0.6$ and $\mathrm{pH}=2$, batch solutions were prepared. Each sample was prepared separately by mixing a known amount of $\mathbf{L}_{2}$ stock solution, a known amount of standardized $\mathrm{HClO}_{4}$ to adjust the $\mathrm{pH}\left(\mathrm{pH}=-\log \left[\mathrm{H}^{+}\right]\right)$and a known amount of $\mathrm{Cu}(\mathrm{II})$ stock solution in the case of the study of the complexes $([\mathrm{Cu}(\mathrm{II})] /[\mathbf{L})=1)$. An absorption spectrum of each sample was recorded in a $1 \mathrm{~cm}$ quartz suprasil spectrophotometric cell using a Varian (Cary 3) UV-Visible spectrophotometer. Between pH 2 and 12.5, direct titrations were carried out. Typically, an aliquot of $10 \mathrm{~mL}$ of $\mathbf{L}$ solution was introduced into a thermostated jacketed titration vessel $\left(25.0(2)^{\circ} \mathrm{C}\right)$ with 1 equivalent of metal $(\mathrm{M})$ in the case of M:L titrations. A known volume of hydrochloric acid solution was added to adjust the $\mathrm{pH}$ around 
2 and the titrations were carried out by addition of known volumes of potassium hydroxide solution. After each addition, the $\mathrm{pH}$ was allowed to equilibrate, an aliquot was transferred to a $1 \mathrm{~cm}$ quartz suprasil spectrophotometric cell, a spectrum was recorded using a Varian (Cary 3) spectrophotometer, the aliquot was transferred back to the titration vessel and a new addition was made. The free hydrogen ion concentrations were measured with a Mettler Toledo U402-S7/120 ( $\mathrm{pH}$ 0-14) combined glass electrode. Potential differences were given by a Tacussel LPH430T millivoltmeter. Standardization of the millivoltmeter and verification of the linearity of the electrode were performed with three commercial buffer solutions (pH 4.01, 7.01 and 10.01, $25^{\circ} \mathrm{C}$ ). The software Hypspec V1.1.33 was used to determine the coordination model and calculate the stability constants $(\log \beta)$ of the formed species. ${ }^{71,80}$

Acid decomplexation studies. Acid-decomplexation studies were performed under pseudo firstorder conditions on two solutions of $\mathrm{CuL}_{2}$ complex in $5 \mathrm{M} \mathrm{HClO}_{4}$ at $25^{\circ} \mathrm{C}$. Changes in the absorption spectra with time over a period of 20 months were monitored using a Perkin-Elmer Lambda 950 spectrophotometer. $1.98 \times 10^{-4} \mathrm{mmol}$ of $\mathrm{Cu}(\mathrm{II}) \mathbf{L}_{2}$ complex were used to monitor the $\pi$ - $\pi^{*}$ transition at $262 \mathrm{~nm}$ and $8.78 \times 10^{-3} \mathrm{mmol}$ to follow the d-d transition at $680 \mathrm{~nm}$.

Cyclic voltammetry. Cyclic voltammetry (CV) was carried out on the $\mathrm{CuL}_{2}$ complex at room temperature with a PC interfaced Radiometer Analytical MDE150/PST50. The CV experiments were performed using a glassy carbon working electrode $\left(0.071 \mathrm{~cm}^{2}\right.$, BASi). The electrode surface was polished routinely with $0.05 \mu \mathrm{m}$ alumina-water slurry on a felt surface immediately before use. The counter electrode was a Pt coil, and the reference electrode was a $\mathrm{Ag} / \mathrm{AgCl}$ electrode. The $\mathrm{CuL}_{2}$ complex was measured in Ar-degassed water with ionic strength fixed at $0.1 \mathrm{M}$ with $\mathrm{NaClO}_{4}$ and the $\mathrm{pH}$ of the solutions were adjusted with $\mathrm{NaOH}$ and $\mathrm{HClO}_{4}$ solutions. 
Seven different values of $\mathrm{pH}(\mathrm{pH}=2.36,4.04,5.70,7.2,8.55,10.23,11.62)$ and different scan rates $(50-300 \mathrm{mV} / \mathrm{s})$ were considered

\section{Radiolabelling.}

${ }^{64} \mathrm{CuCl}_{2}$ in $0.1 \mathrm{M}$ hydrochloric acid was obtained from the ARRONAX cyclotron (Saint-Herblain, France). Production and purification procedures have already been described ${ }^{81}$ Radiochemical purity was determined by gamma spectroscopy and chemical purity was measured by ICP-AES. Water (18.2 M $2 . \mathrm{cm})$ for aqueous solutions was obtained from a Milli-Q gradient system (Millipore). Radiolabelling of ligand $\mathbf{L}_{2}$ with ${ }^{64} \mathrm{Cu}$ was performed, following the same procedure than the one previously described for ligand $\mathbf{L}_{1} \cdot{ }^{58}$ Post-processed ${ }^{64} \mathrm{Cu}$ eluate diluted in $0.25 \mathrm{M}$ ammonium acetate buffer ( $\mathrm{pH} 5.3$ ) were mixed at room temperature with a ligand stock solution $\left(\left[\mathbf{L}_{2}\right]_{\text {stock }}=4.1 \times 10^{-4} \mathrm{M}\right)$. Four radionuclide batches were used for radiolabeling purposes. Each batch was characterized with regards to its specific activity $\left(\mathrm{SA}\left({ }^{64} \mathrm{Cu}\right)\right.$ per nmol of $\left.\mathrm{Cu}\right)$ and the content of cold metallic impurities. Briefly, the characteristics of each batch (\#1 to \#4) is given : batch \#1 $\left(13.13 \mathrm{MBq} / \mathrm{mL},\left[\mathrm{Cu}^{2+}\right]=4.02 \times 10^{-7} \mathrm{M},[\mathrm{M}]=2.48 \times 10^{-5} \mathrm{M}, \mathrm{SA}\left({ }^{64} \mathrm{Cu}\right)=34.8\right.$ $\mathrm{MBq} / \mathrm{nmol})$, batch \#2 $\left(55.71 \mathrm{MBq} / \mathrm{mL},\left[\mathrm{Cu}^{2+}\right]=2.19 \times 10^{-6} \mathrm{M},[\mathrm{M}]=8.93 \times 10^{-6} \mathrm{M}, \mathrm{SA}\left({ }^{64} \mathrm{Cu}\right)=\right.$ $25.3 \mathrm{MBq} / \mathrm{nmol})$, batch \#3 $\left(38.94 \mathrm{MBq} / \mathrm{mL},\left[\mathrm{Cu}^{2+}\right]=1.53 \times 10^{-6} \mathrm{M},[\mathrm{M}]=8.94 \times 10^{-6} \mathrm{M}\right.$, $\left.\mathrm{SA}\left({ }^{64} \mathrm{Cu}\right)=25.3 \mathrm{MBq} / \mathrm{nmol}\right)$, batch \#4 $\left(9.74 \mathrm{MBq} / \mathrm{mL},\left[\mathrm{Cu}^{2+}\right]=3.8 \times 10^{-7} \mathrm{M},[\mathrm{M}]=8.94 \times 10^{-6}\right.$ $\left.\mathrm{M}, \mathrm{SA}\left({ }^{64} \mathrm{Cu}\right)=25.3 \mathrm{MBq} / \mathrm{nmol}\right)$. Several parameters were scrutinized in repeated experiments such as the $\mathrm{pH}$ of the reaction mixtures, the time and the ligand/metal molar ratio (where [metal] corresponds to the total concentration in metal salts, including non-radioactive contaminants from the source such as $\mathrm{Co}(\mathrm{II}), \mathrm{Cu}(\mathrm{II}), \mathrm{Fe}(\mathrm{II} / \mathrm{III}), \mathrm{Ni}(\mathrm{II})$ and $\mathrm{Zn}(\mathrm{II}))$. In a typical experiments, 500 $\mu \mathrm{L}$ batch solutions were prepared separately by mixing a known amount of ${ }^{64} \mathrm{Cu}$ stock solution (5-40 $\mu \mathrm{L}, 0.5 \mathrm{MBq})$, a known volume of ligand stock solution and a known amount of $\mathrm{AcONH}_{4}$ 
buffer, the $\mathrm{pH}$ being previously adjusted to the desired value $(2 \leq \mathrm{pH} \leq 7)$. The influence of temperature and incubation time on the reaction yield was also investigated on $\mathbf{L}_{2}$ for a $\mathrm{L} / \mathrm{M}$ ratio of 0.25 by heating the samples for $1 \mathrm{~h}$ at $80^{\circ} \mathrm{C}$; the $\mathrm{pH}$ was measured before and after the heating. Radiolabelling was followed by spotting the reaction mixture onto a TLC Flex Plate (silica gel $60 \mathrm{~A}, \mathrm{IF}-254,200 \mu \mathrm{m}$, Merck) followed by elution with conc. aq. $\mathrm{NH}_{3} / \mathrm{MeOH} / \mathrm{H}_{2} \mathrm{O} 1 / 2 / 1(\mathrm{v} / \mathrm{v} / \mathrm{v})$. Quantitative distribution of radioactivity on TLC plates was measured using an electronic autoradiography system (Cyclone, Perkin Elmer). Under these conditions the ${ }^{64} \mathrm{Cu}$ complexes $\left(\mathrm{R}_{\mathrm{f}}\right.$ $=0.9)$ and the free ${ }^{64} \mathrm{Cu}\left(\mathrm{R}_{\mathrm{f}}<0.1\right)$ are well separated. All yields are given with the experimental uncertainties of the cyclone device of $\pm 5 \%$.

\section{Results and Discussion.}

\section{Synthesis of ligand $\mathbf{L}_{2}$.}




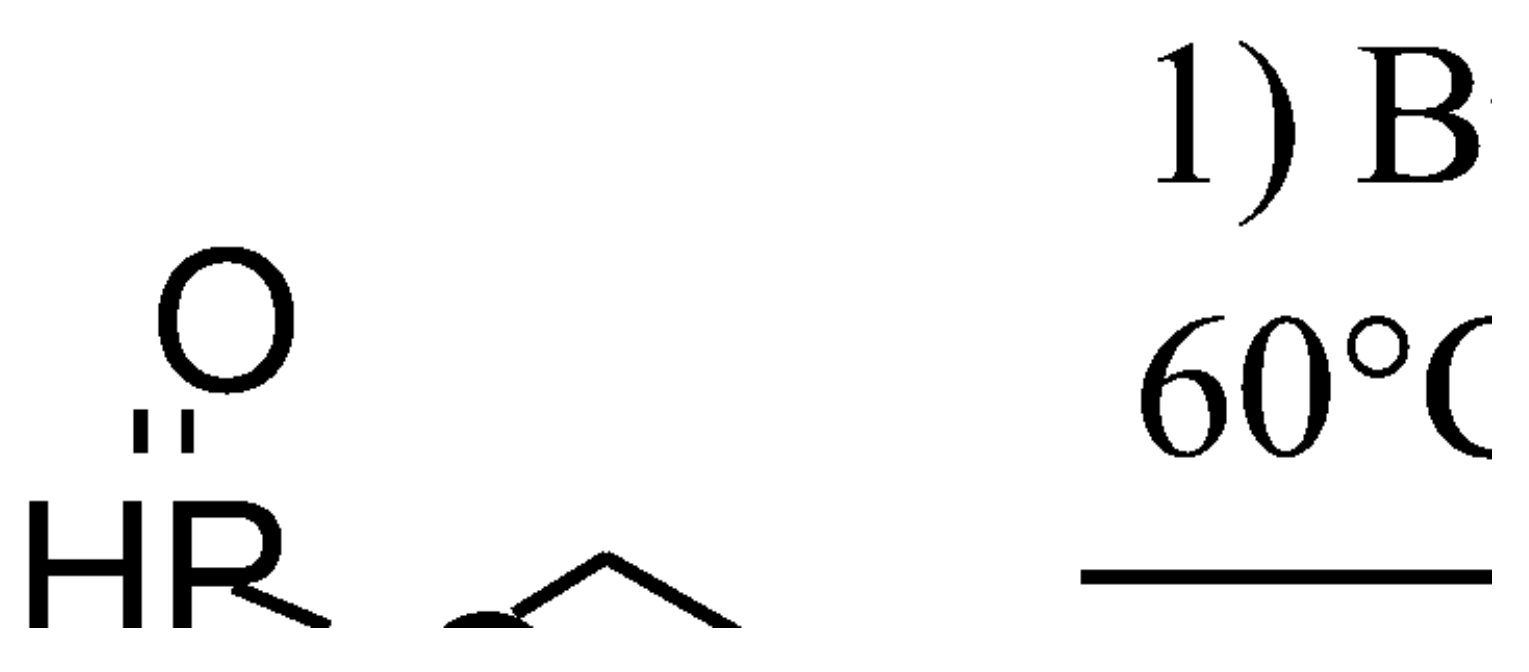

Scheme 1. Synthesis of Ligand $\mathbf{L}_{2}$.

Ligand $\mathbf{L}_{2}$ was obtained in three steps from (aminomethyl)phosphonic acid $\mathbf{1}$ and the piperidinone precursor $\mathbf{P}_{1}$ following a similar synthetic strategy to that previously reported for the glycinate derivative $\mathbf{L}_{1}$ (Scheme 1 ). ${ }^{21} \mathbf{1}$ was quantitatively obtained by a Kabachnik-Fields reaction between diethyl phosphite, methanal and dibenzylamine. Hydrogenolysis of the benzyl protecting groups followed by acid hydrolysis of the diethyl ester moieties were performed by using standard conditions. Bispidone 2 was obtained in 35\% by a double Mannich reaction between $\mathbf{P}_{1}, \mathbf{1}$ and methanal in the presence of $\mathrm{NaHCO}_{3}$. By this method, pure bispidone $\mathbf{2}$ could be obtained by precipitation from ethanol. It can be noticed that previous attempts using diethyl(aminomethyl)phosphonate instead of the phosphonic acid lead to a mixture of products 
which was difficult to purify by crystallizations or column chromatography. Selective reduction of the central ketone of $\mathbf{2}$ was achieved in good yield by addition of $\mathrm{NaBH}_{4}$ in cold methanol ($78^{\circ} \mathrm{C}$ ). A single epimer, with $\mathrm{H}_{9}$ pointing toward $\mathrm{N}_{7}$ was isolated after purification by reverse phase flash chromatography (FPLC) on a C18 column as evidenced by ${ }^{1} \mathrm{H}-{ }^{1} \mathrm{H}$ NOESY experiments. Interestingly, the same regioselectivity was previously observed with the acetatesubstituted bispidol ${ }^{21}$ suggesting a facial regioselectivity, which is probably due to the stabilization of the borohydride intermediate due to formation of hydrogen bonds with the carbonyl and the acid protons of the phosphonic or carboxylic acid on $\mathrm{N}_{7}$ (see numbering on Scheme 1). Saponification of the methyl ester substituents was achieved at room temperature in presence of sodium hydroxide and the pure ligand could be isolated by reverse phase FPLC (see Supporting Information, Figures S1-S13 for the NMR spectra of 2, 3 and $\mathbf{L}_{2}$ ).

Structural characterization of $\mathbf{2}$ and $\mathbf{L}_{2}$. Single crystals of $\mathbf{2}$ (as the sodium salt $2 \mathrm{Na}$ ) and $\mathbf{L}_{2}$ were obtained by slow evaporation of methanol solutions at room temperature. The crystal structure refinement confirms the chemical structure of $\mathbf{2}$ and ligand $\mathbf{L}_{2}$. The corresponding ORTEP view of the asymmetric unit is shown in Figure and 2, respectively and corresponding crystallographic data are presented in Tables 1 and 2. 


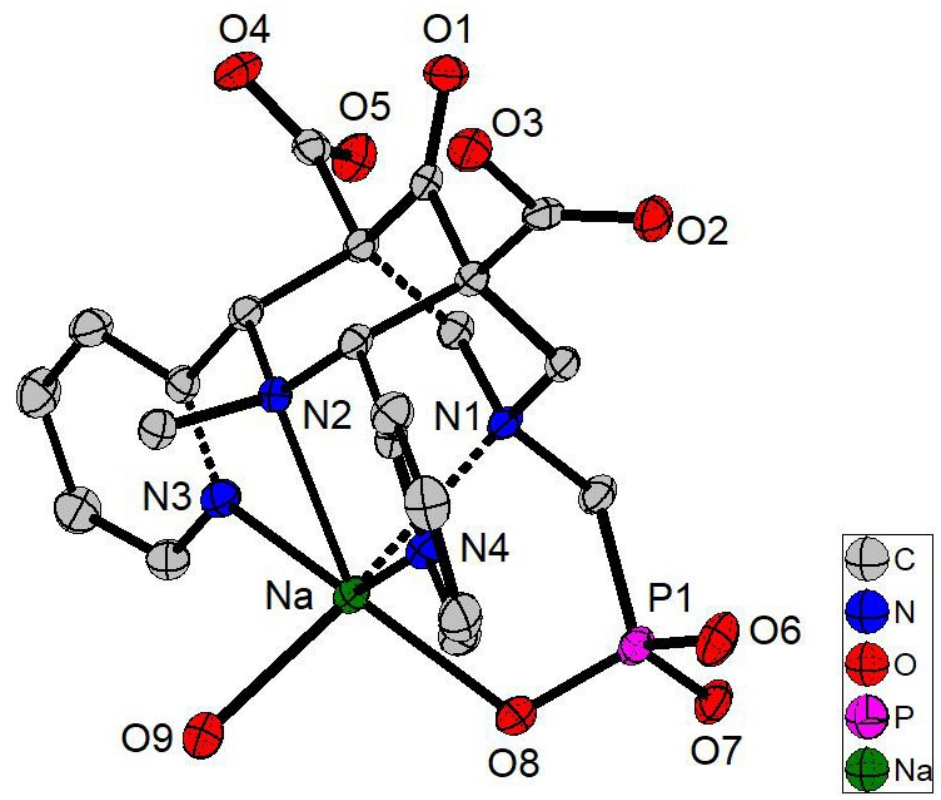

Figure 1. ORTEP drawing of $\mathbf{2} \mathbf{N a}$ with the main atomic numbering. Thermal ellipsoids drawn at $50 \%$ probability level. All $\mathrm{H}$ atoms are omitted for the sake of clarity.

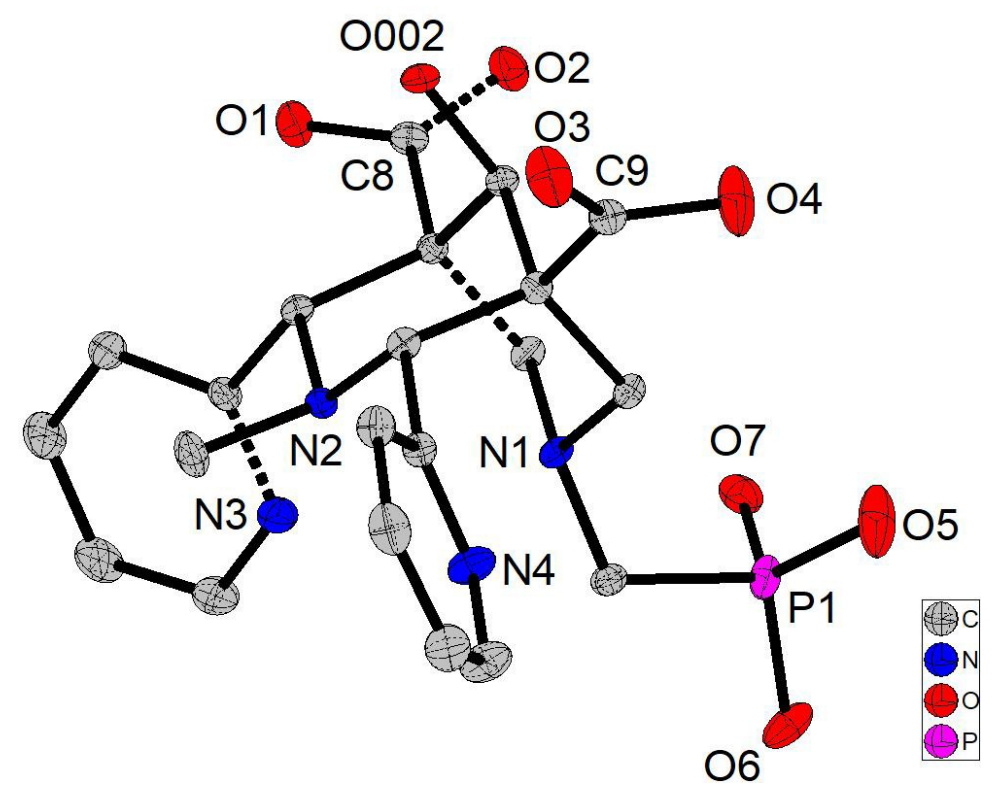

Figure 2. ORTEP drawing of ligand $\mathbf{L}_{2}$ with the main atomic numbering. Thermal ellipsoids drawn at $50 \%$ probability level. All $\mathrm{H}$ atoms are omitted for the sake of clarity. 
Table 2. Crystallographic data for the structures of $\mathbf{2 N a}, \mathbf{L}_{2}$ and $\mathbf{L}_{3}{ }^{72}$

\begin{tabular}{|c|c|c|c|}
\hline & $2 \mathrm{Na}$ & $\mathbf{L}_{2}$ & $\mathbf{L}_{3}$ \\
\hline Formula & $\begin{array}{c}\mathrm{C}_{24} \mathrm{H}_{30} \mathrm{~N}_{4} \mathrm{NaO}_{9} \mathrm{P} \\
\mathrm{MeOH}\end{array}$ & $\begin{array}{c}\mathrm{C}_{21} \mathrm{H}_{25} \mathrm{~N}_{4} \mathrm{O}_{8} \mathrm{P} \\
2 \mathrm{MeOH}\end{array}$ & $\mathrm{C}_{26} \mathrm{H}_{30} \mathrm{~N}_{4} \mathrm{O}_{7}$ \\
\hline Molecular weight $\left(\mathrm{g} \cdot \mathrm{mol}^{-1}\right.$ ) & 604.52 & 556.50 & 510.54 \\
\hline Temperature (K) & $150(2)$ & $150(2)$ & $173(2)$ \\
\hline Crystal size (mm) & $041 \times 0.24 \times 0.11$ & $0.55 \times 0.49 \times 0.43$ & $0.30 \times 0.25 \times 0.20$ \\
\hline Crystal system & Triclinic & Monoclinic & Monoclinic \\
\hline Space group & $\mathrm{P}-1$ & $\mathrm{P} 2{ }_{1} / \mathrm{n}$ & $\mathrm{P} 2{ }_{1} / \mathrm{c}$ \\
\hline Unit-cell dim. $\left(\AA,^{\circ}\right)$ & $\begin{array}{c}a=8.3045(2) \\
b=13.5397(5) \\
c=14.3175(6) \\
\alpha=113.495(2) \\
\beta=91.526(2) \\
\gamma=93.495(2)\end{array}$ & $\begin{array}{c}a=13.4531(5) \\
b=10.6527(3) \\
c=18.3216(7) \\
\beta=92.1580(10)\end{array}$ & $\begin{array}{l}a=14.8091(4) \\
b=11.8613(4) \\
c=14.8551(4) \\
\beta=100.775(2)\end{array}$ \\
\hline Volume $\left(\AA^{3}\right) ; \mathrm{Z}$ & $1471.37(9) ; 2$ & 2623.84(16); 4 & 2563.37(13); 4 \\
\hline Density (calc.) (g.cm ${ }^{-3}$ ) & 1.364 & 1.409 & 1.323 \\
\hline Abs. coeff. $\left(\mathrm{mm}^{-1}\right)$ & 0.168 & 0.167 & 0.097 \\
\hline$F(000)$ & 636 & 1176 & 1080 \\
\hline$\theta_{\max }$ & 27.48 & 27.52 & 27.46 \\
\hline Reflections collected & 14303 & 23378 & 25582 \\
\hline $\begin{array}{l}\text { Independent reflections } \\
(\mathrm{I}>2 \sigma(\mathrm{I}))\end{array}$ & 4964 & 5409 & 5860 \\
\hline Parameters & 378 & 357 & 338 \\
\hline $\mathrm{R} 1, \mathrm{wR} 2(\mathrm{I}>2 \sigma(\mathrm{I}))$ & $0.0511,0.1307$ & $0.0367,0.098$ & $0.0566,0.1418$ \\
\hline R1, wR2 (all data) & $0.0695,0.1433$ & $0.041,0.1017$ & $0.0832,0.1555$ \\
\hline
\end{tabular}

Table 3. Selected Bond Lengths and Angles in $\mathbf{2}, \mathbf{L}_{2}$ and $\mathbf{L}_{3} .{ }^{72}$

\begin{tabular}{ccc}
\hline & $\mathbf{2}$ & $\mathbf{L}_{2}$ \\
\hline & & $\mathbf{L}_{3}$ \\
Na-N1 & $2.6205(18)$ & \\
Na-N2 & $2.4551(15)$ & \\
Na-N3 & $2.4802(23)$ & \\
Na-N4 & $2.4917(24)$ &
\end{tabular}




\begin{tabular}{|c|c|c|c|}
\hline Na-O8 & $2.3330(15)$ & & \\
\hline Na-O9 & $2.3695(18)$ & & \\
\hline $\mathrm{N} 1 \cdots \mathrm{N} 2$ & $2.9429(24)$ & 2.6935(13) & $2.888(2)$ \\
\hline \multirow[t]{2}{*}{$\mathrm{N} 3 \cdots \mathrm{N} 4$} & $4.6521(31)$ & 4.6913(16) & 7.186(2) \\
\hline & & Angles (deg) & \\
\hline Pyr1 $\cdots$ Pyr2 & 144.05 & 116.8 & 159.8 \\
\hline
\end{tabular}

The intermediate $\mathbf{2}$ was isolated as a sodium salt and the structure (Figure 1) confirms the chairchair conformation of the bispidone, as observed by ${ }^{1} \mathrm{H}$ NMR studies (Figure S1). This intermediate was crystallized in the triclinic P-1 space group with one sodium complex and one methanol molecule in general positions. The $\mathrm{Na}(\mathrm{I})$ ion is hexacoordinated by ligand 2 and one methanol molecule with a distorted octahedral coordination geometry (Table 2), which is, as expected from the strong rigidity of the ligand backbone, very similar to other hexacoordinated structures with $\mathrm{Li}(\mathrm{I})^{82}$ or transition metal ions such as $\mathrm{Cr}(\mathrm{III}), \mathrm{Mg}(\mathrm{II}), \mathrm{Fe}(\mathrm{II}), \mathrm{Co}(\mathrm{II}), \mathrm{Cu}(\mathrm{I} / \mathrm{II})$ or $\mathrm{Zn}(\mathrm{II}){ }^{5}$ In the case of $\mathbf{L}_{2}$, the asymmetric unit contains one complete $\mathbf{L}_{2}$ ligand and 2 methanol molecules in general positions (Figure 2). The ligand crystallizes in a partially protonated form in the monoclinic space group $P 2_{1} / n$ (Table 2 ) and is characterized by the presence of four acidic protons: one on the carboxylic acid (C9-O4H = 1.3150(16) and C9=O3 = 1.2035(16) $\AA$ ), two on the phosphonic acid $(\mathrm{P} 1=\mathrm{O} 5=1.4779(0), \mathrm{P} 1=\mathrm{O} 6 \mathrm{H}=1.5598(10)$ and $\mathrm{P} 1=\mathrm{O} 7 \mathrm{H}=1.5616(10) \AA)$ and a last one localized on the tertiary amine $\mathrm{R}_{3} \mathrm{NH}^{+}\left(\mathrm{N}_{2}-\mathrm{H}_{2}=0.894(17) \AA\right)$. The carbon-oxygen distances on the remaining carboxylate are almost identical $\left(\mathrm{C}_{8}-\mathrm{O}_{1}=1.2534(15)\right.$ and $\mathrm{C}_{8}-\mathrm{O}_{2}$ 1.2642(15) and the oxygen atoms $\mathrm{O}_{1}$ and $\mathrm{O}_{2}$ are involved in hydrogen bonds with a bidentate phosphonate of a neighboring molecule. Furthermore, the ammonium proton $\mathrm{H}_{2}$ is stabilized inside the cavity by strong hydrogen bonds with the nitrogen atoms $\mathrm{N}_{1}\left(d_{\mathrm{H}-\mathrm{N} 1}=2.1142(105) \AA\right)$, $\mathrm{N}_{3}\left(d_{\mathrm{H}-\mathrm{N} 3}=2.3543(78) \AA\right)$ and $\mathrm{N}_{4}\left(d_{\mathrm{H}-\mathrm{N} 4}=2.5267(86) \AA\right)$. Deeper analysis of the Fourier transform of the structure factors did not reveal any residual electron density around nitrogen 
atom N1, meaning that in solid state, the proton is exclusively well-localized on the nitrogen atom N2. This protonation scheme is typical of a "proton sponge" behavior, which was confirmed by physicochemical titrations (see below). As a consequence, ligand $\mathbf{L}_{2}$ is highly preorganized for metal complexation with (i) a chair-chair conformation of the bispidine skeleton, (ii) a cis-symmetrical configuration of the pyridine rings and (iii) the lone pairs of $\mathrm{N}_{1}$ and $\mathrm{N}_{2}$ pointing towards the inside of the cavity. In addition, the $\mathrm{N}_{1} \cdots \mathrm{N}_{2}=2.6935(13)$ and $\mathrm{N}_{3} \cdots \mathrm{N}_{4}=4.6913(16) \AA$ distances are significantly shorter than for analogous bispidone in their deprotonated form $\left(\mathrm{N}_{1} \cdots \mathrm{N}_{2}=2.888(2) \text { and } \mathrm{N}_{3} \cdots \mathrm{N}_{4}=7.186(2) \AA \text { for } \mathbf{L}_{3}\right)^{72}$ and very close to the distances measured for $\mathbf{2} \mathbf{N a}$ and for another recent example of protonated structure with Hbispa ligands $\left(\mathrm{N}_{1} \cdots \mathrm{N}_{2}=2.684(2)\right.$ and $\mathrm{N}_{3} \cdots \mathrm{N}_{4}=4.922(3) \AA$ for Hbispa1a) ${ }^{83}$ This contraction of the cavity is also likely attributed to the presence of the protonated ammonium center which more strongly attracts the electron-rich surrounding nitrogen atoms. Moreover, the structure is stabilized by a network of strong hydrogen bonds between the phosphonic acids and the acetate moiety of a neighboring molecule $\left(\mathrm{O}_{1}-\mathrm{O}_{6}=2.5404(13) \AA, \mathrm{O}_{1}-\mathrm{H}_{6 \mathrm{~A}}-\mathrm{O}_{6}=169.8(2)^{\circ}, \mathrm{O}_{2}-\mathrm{O}_{7}=\right.$ 2.5632(13) $\left.\AA, \mathrm{O}_{2}-\mathrm{H}_{7 \mathrm{~A}}-\mathrm{O}_{7}=177.8(2)^{\circ} \AA\right)$, which stabilizes this particular protonation state. Finally, each ligand form moderate H-bonds $\left(\mathrm{O}_{2}-\mathrm{O}_{8}=2.8016(18) \AA \mathrm{O}_{2}-\mathrm{H}_{8}-\mathrm{O}_{8}=157.2(1)^{\circ}, \mathrm{O}_{9}\right.$ $\left.\mathrm{O}_{002}=2.6677(16) \AA, \mathrm{O}_{002}-\mathrm{H}_{002}-\mathrm{O}_{9}=166.5(2)^{\circ}\right)$ with two methanol molecules, the first one bridging the acetate group and the hydroxyl at $\mathrm{C}_{9}$ and the second one being linked to the phosphonic acid. The rigid chair-chair conformation of the bicycle was also observed in solution by ${ }^{1} \mathrm{H}$ NMR (Figure S9) with typical Overhauser effect between the pyridyl protons $\mathrm{H}_{\mathrm{d}}$ and the equatorial protons $\mathrm{H}_{6}$ (see Figure $\mathrm{S} 13$ for ${ }^{1} \mathrm{H}-{ }^{1} \mathrm{H}$ NOESY). Attempts of growing single crystals of the $\mathrm{CuL}_{2}$ complex have also been carried out unfortunately leading to crystals of insufficient quality for X-ray diffraction. 


\section{Thermodynamic Studies.}

\section{Protonation constants of ligand $L_{2}$.}

Ligand $\mathbf{L}_{2}$ (Chart 1) has five protonable sites in the usual $2 \leq \mathrm{pH} \leq 12$ window in water: two tertiary amines, two carboxylic acids and one phosphonic acid. The crystal structure of $\mathbf{L}_{2}$ suggests that only one of two tertiary amines is protonated. However, three potential additional protonations constants have to be taken into account at lower $\mathrm{pH}$ values, which account for the second protonation of the phosphonic acid and for the protonations of the two pyridine rings. ${ }^{21}$ Protonation constants, as defined by equations $\underline{1}$ and $\underline{2}$, were determined by a combination of potentiometric titrations (Figure S14) and UV-Visible absorption titrations versus $\mathrm{pH}$ between $\mathrm{pH}-0.6$ and 12 (Figure 3).

$$
\begin{aligned}
& L H \mathrm{n}-1+H \leftrightarrow L H \mathrm{n} \\
& K_{n}^{H}=\frac{[L H \mathrm{n}]}{[L H \mathrm{n}-1][H]} \mathrm{n}=1-6
\end{aligned}
$$

Because of the known strong stability of the metal complexes of bispidine derivatives, ${ }^{4,20}$ ligand $\mathbf{L}_{2}$ and its metal complexes were also studied in strongly acidic conditions $(-0.59<\mathrm{pH}<1.73)$ by means of spectrophotometric titrations vs $\mathrm{pH}$. As such low $\mathrm{pH}$ cannot be measured with an electrode, the batch titration technique was used and the $\mathrm{pH}$ of the solutions was fixed by adding known volumes of standardized $\mathrm{HClO}_{4}$ (see Experimental Section for details). It has to be noted that the ionic strength was not fixed below $\mathrm{pH} 1$ in the batch titrations and that no decomposition of the ligand was observed, even in strongly acidic conditions. The spectral variations of $\mathbf{L}_{2}$ observed between $-0.59<\mathrm{pH}<1.73$ (batch titration) and $2.10<\mathrm{pH}<11.93$ (direct titration) 
were combined in Figure 3. $\mathbf{L}_{2}$ showed one band, centered at $263 \mathrm{~nm}$, attributed to the $\pi-\pi^{*}$ transition of the pyridine rings, which underwent a hypochromic variation with the appearance of shoulders upon increase of the $\mathrm{pH} .{ }^{60}$ The hypochromic variation is typical of the deprotonation of pyridinium nitrogens while the shoulders appearing in basic conditions suggest the existence of hydrogen bonding with at least one pyridine nitrogen lone pair. ${ }^{84}$

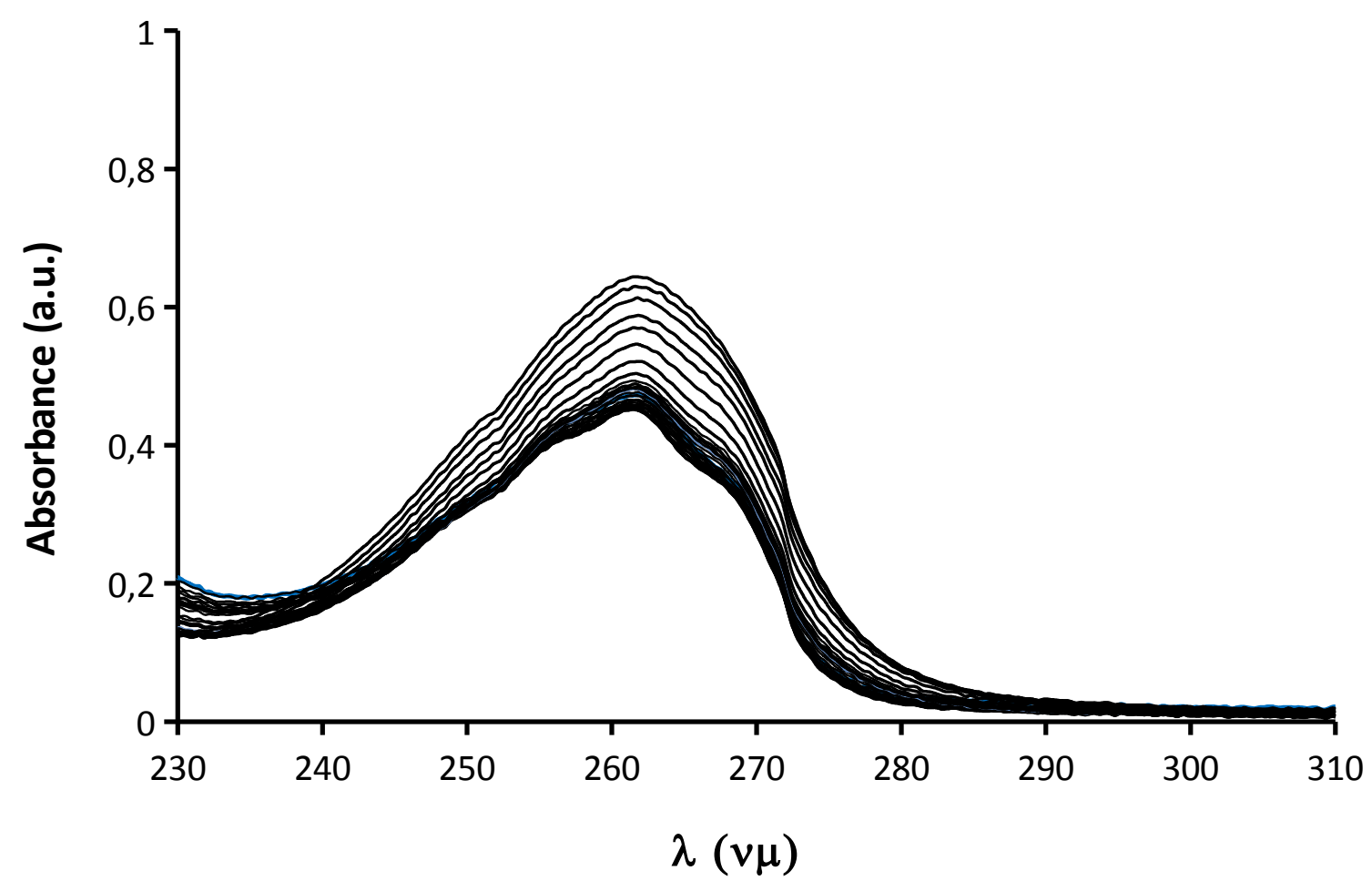

Figure 3. Spectrophotometric titrations of $\mathbf{L}_{2}$ vs $\mathrm{pH}$ between $-0.6<\mathrm{p}[\mathrm{H}]<1.73$ (Batch titration) and $2.10 \leq \mathrm{pH} \leq 11.93$ (Direct titration). $\left[\mathbf{L}_{2}\right]_{\mathrm{tot}}=4.80 \times 10^{-5} \mathrm{M}$, Solvent: $\mathrm{H}_{2} \mathrm{O} ; I=0.1 \mathrm{M} \mathrm{KCl} ; T$ $=25.0(2)^{\circ} \mathrm{C}$.

The statistical analysis of the potentiometric and spectrophotometric data versus $\mathrm{pH}$ was achieved with Hyperquad2008 85 and Hypspec softwares, ${ }^{78}$ respectively, and led to the determination of five protonation constants of ligand $\mathbf{L}_{2}$ in the $\mathrm{pH}$ range from -0.59 to 11.93 (Table 4). The first protonation constant $\left(\log K_{1}^{\mathrm{H}}=11.5(3)\right)$ was assigned to the tertiary amine of 
the bispidine skeleton. ${ }^{82,86,87,88}$ From crystallographic data, It was postulated that simultaneous protonation of the two tertiary amines does not occur. The second protonation constant $\left(\log K_{2}{ }^{\mathrm{H}}=\right.$ 7.2(1)) was attributed to the first protonation of the phosphonic acid. The third and fourth protonation constants $\left(K_{3}{ }^{\mathrm{H}}, K_{4}{ }^{\mathrm{H}}\right)$ were attributed to the two carboxylic acid oxygens. The two most acidic protonation constants belong to the pyridine nitrogens and/or to the second protonation of the phosphonic acid. Only one of them could be determined from our spectrophotometric batch titrations $\left(\log K_{5}^{\mathrm{H}}=0.5(1)\right)$. These protonation constants are in good agreement with those determined previously for ligand $\mathbf{L}^{1}$ and for the analogue of $\mathbf{L}_{2}$ bearing a thiophene group in place of the phosphonic acid. ${ }^{21}$

Table 4. Successive Protonation Constants of $\mathbf{L}_{2}$ and $\mathbf{L}_{1}$

\begin{tabular}{lccc}
\hline $\mathrm{p} K_{n}{ }^{H}$ & & $\mathbf{L}_{2}$ & $\mathbf{L}_{\mathbf{1}}$ \\
\hline $\mathrm{p} K_{1}{ }^{H}$ & $\mathrm{~N}_{\text {tert }}$ & $11.5(3)$ & $10.6(6)$ \\
$\mathrm{p} K_{2}{ }^{H}$ & $\mathrm{HPO}_{3}{ }^{-}$ & $7.2(1)$ & $/$ \\
$\mathrm{pK}_{3}{ }^{\mathrm{H}}$ & $\mathrm{COOH}$ & $3.8(3)$ & $4.5(1)$ \\
$\mathrm{p} K_{4}{ }^{H}$ & $\mathrm{COOH}$ & $2.4(4)$ & $2.0(2)$ \\
$\mathrm{p} K_{5}{ }^{H}$ & $\mathrm{PO}_{3}{ }^{2-} / \mathrm{N}_{\mathrm{pyr}}$ & $0.5(1)$ & $0.82(1)$ \\
$\mathrm{p} K_{6}{ }^{H}$ & $\mathrm{~N}_{\mathrm{pyr}}$ & $<0.5$ & $<0.82$ \\
\hline
\end{tabular}

$\mathrm{H}_{2} \mathrm{O}, I=0.1 \mathrm{M}(\mathrm{KCl}), T=25.0^{\circ} \mathrm{C}$. The numbers in parentheses correspond to the standard deviations expressed as the last significant digit.

From these values, the electronic spectra of the protonated species of $\mathbf{L}_{2}$ (Figure 4a) and their distribution diagram (Figure 4b) were calculated. ${ }^{89}$ The distribution curves showed that, due to the presence of the phosphonate moiety $\left(\mathrm{p} K_{2}^{H}=7.2(1)\right)$, the ligand exists in its $\mathbf{L}_{2} \mathbf{H}^{3-}$ and $\mathbf{L}_{2} \mathbf{H}_{2}{ }^{2-}$ forms under physiological conditions ( $\mathrm{pH}$ 7.4). 
a)

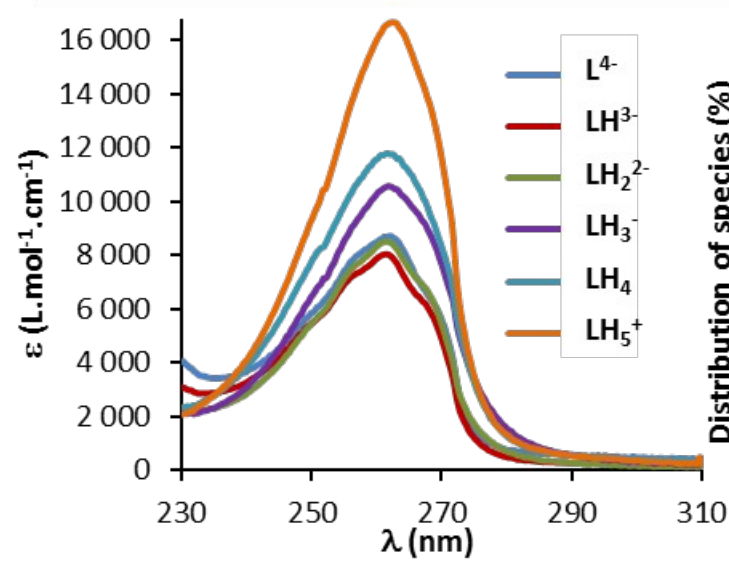

b)

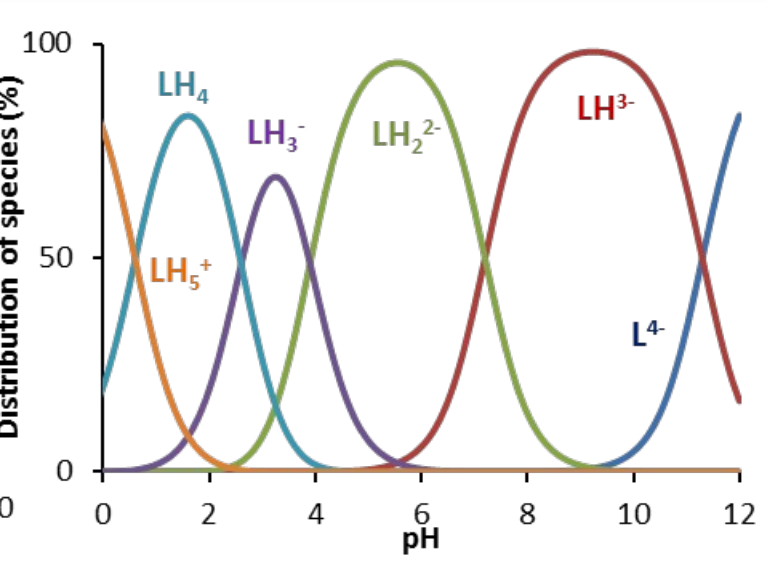

Figure 4. (a) Electronic spectra and (b) distribution diagram of the protonated species of $\mathbf{L}_{2}$ $\left(\left[\mathbf{L}_{2}\right]_{\text {tot }}=5.0 \times 10^{-5} \mathrm{M}, \mathrm{H}_{2} \mathrm{O}, I=0.1 \mathrm{M} \mathrm{KCl}, T=25.0(2){ }^{\circ} \mathrm{C}\right)$.

\section{Stability constants of the $\mathrm{Cu}(\mathrm{II})$ and $\mathrm{Zn}(\mathrm{II})$ complexes.}

Spectrophotometric titrations versus $\mathrm{pH}$ of solutions of $\mathbf{L}_{2}$ and $\mathrm{Cu}(\mathrm{II})$ were carried out between $\mathrm{pH}=-0.59$ and 2 (batch titration) to ensure complete decomplexation of $\mathrm{Cu}(\mathrm{II})$ and between $\mathrm{pH}$ $=2$ and 12 (direct titration) both on the ligand bands and on the $\mathrm{Cu}(\mathrm{II}) \mathrm{d}-\mathrm{d}$ bands (Figure 5). The position of the $\mathrm{Cu}(\mathrm{II}) \mathrm{d}-\mathrm{d}$ bands at $\mathrm{pH}=2\left(\lambda_{\max }=682 \mathrm{~nm}\right)$ shows that the $\mathrm{Cu}(\mathrm{II})$ complex is already formed at this $\mathrm{pH}$ and suggests a square pyramidal geometry. ${ }^{90}$ Significant changes were seen in the UV-visible absorption spectra of $\mathrm{CuL}_{2}$ as a function of $\mathrm{pH}$, where the hypo- and hypsochromic shift of the main band at $260 \mathrm{~nm}$ together with the appearance of a small charge transfer band (Figure 5a) ${ }^{61}$ indicated the complete formation of the complex at $\mathrm{pH}=0.2$. Further spectral variations were observed between $\mathrm{pH} 2$ and 12 suggesting the successive formation of different species. 
a)

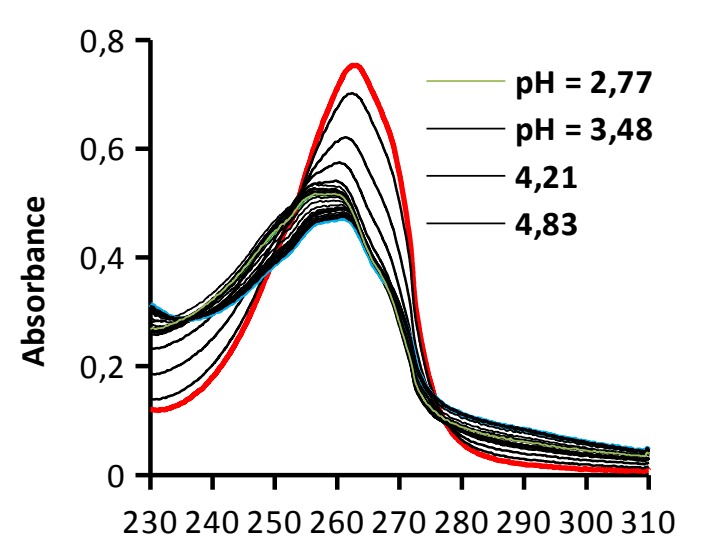

$\lambda(\nu \mu)$ b)

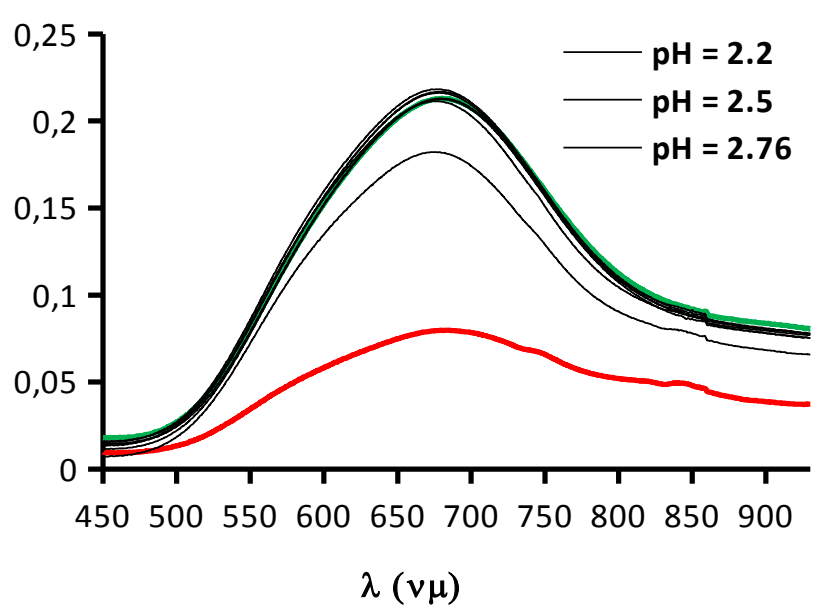

Figure 5. Spectrophotometric titration of $\mathrm{Cu} \mathrm{L}_{2}$ vs $\mathrm{pH}$ : (a) $\left[\mathbf{L}_{2}\right]_{\mathrm{tot}}=4.79 \times 10^{-5} \mathrm{M},[\mathrm{Cu}(\mathrm{II})]_{\mathrm{tot}} /$ $\left[\mathbf{L}_{2}\right]_{\text {tot }}=0.97,-0.60<\mathrm{pH}<11.99, \mathrm{H}_{2} \mathrm{O}, I=0.1 \mathrm{M}(\mathrm{KCl}), T=25.0(2){ }^{\circ} \mathrm{C} .(\mathrm{b})\left[\mathbf{L}_{2}\right]_{\mathrm{tot}}=2.50 \times 10^{-3}$ $\mathrm{M},[\mathrm{Cu}(\mathrm{II})]_{\mathrm{tot}} /\left[\mathbf{L}_{2}\right]_{\mathrm{tot}}=0.97,-0.61<\mathrm{pH}<12.07, \mathrm{H}_{2} \mathrm{O}, I=0.1 \mathrm{M}(\mathrm{KCl}), \mathrm{T}=25.0(2)$.

Data analysis ${ }^{85,78}$ suggested that the best model involves the successive formation of $\mathrm{CuL}_{2} \mathrm{H}_{2}$, $\mathrm{CuL}_{2} \mathrm{H}$ and $\mathrm{CuL}_{2}$ over the entire studied $\mathrm{pH}$ range (Table 5) with high stability constants. This model was confirmed by potentiometric titrations between $\mathrm{pH}$ 2-12 in which the $\mathrm{CuL}_{2} \mathrm{H}_{2}$ stability constant, determined from the batch titration, was fixed.

We then focused our attention on the study of the complexation of $\mathrm{Zn}$ (II) since it is a common metallic impurity in no-carrier-added radiocopper solutions. ${ }^{81}$ Potentiometric and spectrophotometric titrations versus $\mathrm{pH}$ of $\mathbf{L}_{2}$ with stoichiometric amounts of $\mathrm{Zn}(\mathrm{II})$ showed the same model of complexation than for $\mathrm{Cu}(\mathrm{II})$, i.e. the successive formation of $\mathrm{Zn}_{2} \mathrm{H}_{2}, \mathrm{Zn} \mathbf{L}_{2} \mathrm{H}$ and $\mathrm{Zn} \mathbf{L}_{2}$ species. 
Table 5. Overall Stability Constants $(\log \beta)$ of the $M \mathbf{L}_{2}$ and $\mathbf{M L}_{1}$ Complexes

\begin{tabular}{|lcccc|}
\hline & \multicolumn{2}{c}{$\mathrm{Cu}(\mathrm{II})$} & \multicolumn{2}{c|}{$\mathrm{Zn}(\mathrm{II})$} \\
\hline $\log \beta_{\mathrm{ML}}$ & $\mathbf{L}_{1}$ & $\mathbf{L}_{2}$ & $\mathbf{L}_{1}$ & $\mathbf{L}_{2}$ \\
$\mathrm{p} K a_{1}$ & $19.2(3)$ & $22.5(1)$ & $14.45(2)$ & $18.8(1)$ \\
$\mathrm{pKa} a_{2}$ & & $4.9(3)$ & & $5.3(2)$ \\
$\mathrm{pM}(\mathrm{pH} 7.4)$ & & $3.1(3)$ & & $3.1(2)$ \\
& 17.0 & 19.1 & 12.2 & 15.4 \\
\hline
\end{tabular}

${ }^{\mathrm{a}} \mathrm{M}=\mathrm{Cu}(\mathrm{II}), \mathrm{Zn}(\mathrm{II}), \mathrm{H}_{2} \mathrm{O} ; I=0.1 \mathrm{M} ; T=25.0^{\circ} \mathrm{C}, \beta_{\mathrm{MLH}}=[\mathrm{MLH}] /([\mathrm{M}][\mathrm{L}][\mathrm{H}]) ;$ charges were omitted for clarity; $\log K_{\mathrm{Cu}(\mathrm{OH})}=-6.29 ; \log K_{\mathrm{Cu}(\mathrm{OH})^{2}}=-13.1 ; \log K_{\mathrm{Zn}(\mathrm{OH})}=-7.89 ; \log K_{\mathrm{Zn}(\mathrm{OH})^{2}}=$ -14.92 (from ref 91). $\mathrm{pM}=-\log \left[\mathrm{M}(\mathrm{II})_{\text {free }}\right]$ with $[\mathrm{M}]=10^{-6} \mathrm{M},[\mathrm{L}]=10^{-5} \mathrm{M}, \mathrm{pH}$ 7.4.

In order to compare the chelating ability of $\mathbf{L}_{2}$ for $\mathrm{Cu}(\mathrm{II})$ and $\mathrm{Zn}(\mathrm{II})$ with other ligands, their $\mathrm{pM}$ $(\mathrm{M}=\mathrm{Cu}(\mathrm{II}), \mathrm{Zn}(\mathrm{II}))$ values at physiological $\mathrm{pH}(\mathrm{pH}$ 7.4) were calculated (Tables 1 and 5). By representing the amount of free metal in solution at physiological $\mathrm{pH}$, the $\mathrm{pM}$ allows to compare the chelation power of ligands having different denticities and protonation properties for various metals. These results indicated a very strong stability of the $\mathrm{Cu}$ (II) complex bearing a phosphonate arm, with a $\mathrm{pCu}$ value two orders of magnitude larger than the previously studied ligand $\mathbf{L}_{1}$ with a carboxylate arm and among the highest observed for ${ }^{64} \mathrm{Cu}$ PET ligands (Table 1). Moreover, ligand $\mathbf{L}_{2}$ showed a good selectivity for $\mathrm{Cu}(\mathrm{II})$ compared to $\mathrm{Zn}(\mathrm{II})$, with more than 3 orders of magnitude increase in $\mathrm{pM}$ values between the $\mathrm{Cu}(\mathrm{II})$ and $\mathrm{Zn}(\mathrm{II})$ complexes.

The electronic spectra of the $\mathrm{Cu}(\mathrm{II})$ and $\mathrm{Zn}$ (II) complexes of $\mathbf{L}_{2}$ (Figure 6a) and their species distribution profiles (Figure 6b) were calculated from their thermodynamic stability constants. The distribution curves show that for both $\mathrm{Cu}(\mathrm{II})$ and $\mathrm{Zn}$ (II), the ML complex is the major species at physiological $\mathrm{pH}(\mathrm{pH}=7.4)$.

a)

b) 

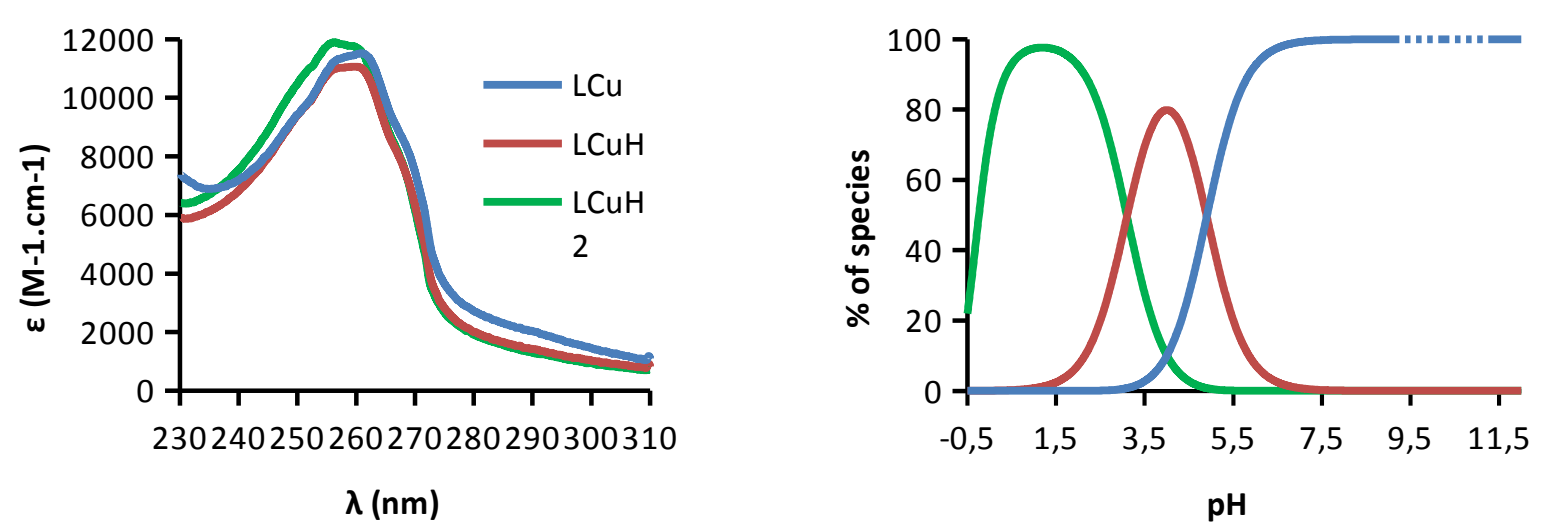

Figure 6. (a) Electronic spectra and (b) distribution diagram of the different $\mathbf{C u}(\mathrm{II})-\mathbf{L}_{2}$ species $\left(\left[\mathbf{L}_{2}\right]_{\text {tot }}=5.05 \times 10^{-5} \mathrm{M},[\mathrm{Cu}]_{\text {tot }}\left[\mathrm{L}_{2}\right]_{\text {tot }}=0.98, \mathrm{H}_{2} \mathrm{O}, I=0.1 \mathrm{M} \mathrm{KCl}, T=25.0(2)^{\circ} \mathrm{C}\right)$.

pKas of the $\mathrm{Zn}(\mathrm{II})$ complexes have been confirmed by variable $\mathrm{pH}{ }^{1} \mathrm{H}$ and ${ }^{31} \mathrm{P}$ NMR spectroscopy of a stoichiometric mixture of $\mathbf{L}_{2}$ and $\mathrm{ZnCl}_{2}$ in $\mathrm{D}_{2} \mathrm{O}$ (Figure 7). At $\mathrm{pD}=12.6$, the ${ }^{1} \mathrm{H}$ NMR spectra is consistent with the formation of a rigid 1:1 complex (Figure S15) and all protons could be assigned by ${ }^{1} \mathrm{H}-{ }^{1} \mathrm{H}$ COSY and NOESY experiments (Figure S16). Significant variations are observed in the chemical shift of the protons $\mathrm{H}_{6 / 8}(\Delta \delta=0.2 \mathrm{ppm}), \mathrm{H}_{\mathrm{e}}(\Delta \delta=0.29 \mathrm{ppm})$, as well as of the phosphorus atom ( $\Delta \delta=4.63 \mathrm{ppm}$ ) (Figure 8, see numbering on Scheme 1). The strong variations on ${ }^{31} \mathrm{P}$ and on $\mathrm{H}_{\mathrm{e}}$ suggest that the first protonation occurs on the phosphonate function and values of $p K a_{1\left(31^{\mathrm{P})}\right.}=5.4$ and $p K a_{1(\mathrm{H} 6)}=5.3$ could be determined from the analysis of the chemical shift of the ${ }^{31} \mathrm{P}$ atom and proton $\mathrm{H}_{6}$, respectively (Figure $7 \mathrm{c}$ ). These results are in very good agreement with the $\mathrm{pKa}_{1}$ obtained from potentiometric and spectrophotometric titrations. Protonation of the phosphonate also influences the chemical shift of the $\mathrm{H}_{6 / 8}$ protons in the $4.8 \leq \mathrm{pH} \leq 7.2$ range. Moreover, the protonation curve of $\mathrm{H}_{6 / 8}$ eq clearly indicates that a second protonation reaction takes place below $\mathrm{pH} 4$, which could be assigned to the protonation of a carboxylate function. 
a)

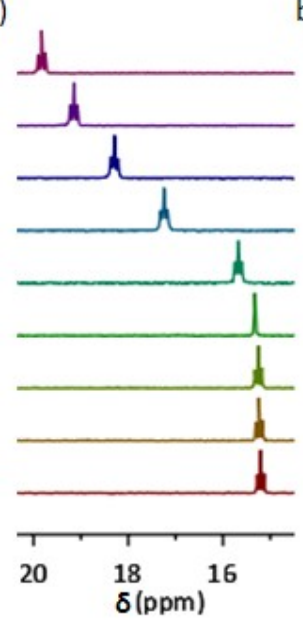

b)

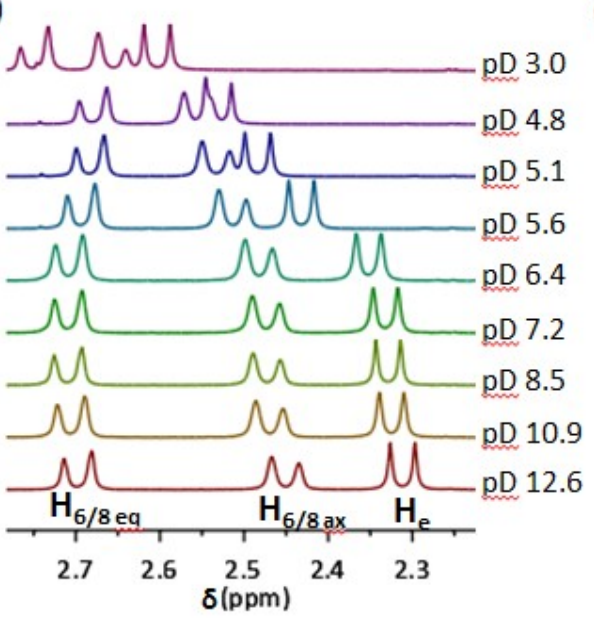

c)

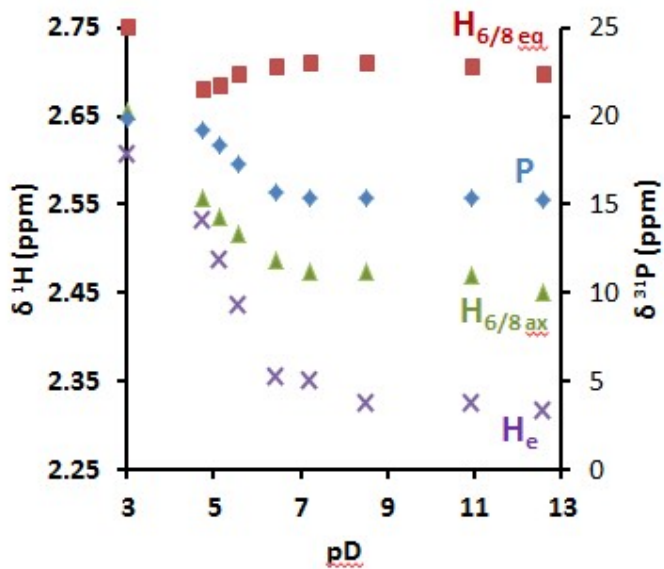

Figure 7. Variable $\mathrm{pH}$ NMR of a $\mathbf{L}_{2}: \mathrm{ZnCl}_{2} 1: 1$ solution in $\mathrm{D}_{2} \mathrm{O}$ at $25^{\circ} \mathrm{C}$ : (a) ${ }^{31} \mathrm{P}$ NMR spectra; (b) Zoom of the ${ }^{1} \mathrm{H}$ NMR spectra in the 2.25-2.75 ppm region; (c) Protonation curves $=\mathrm{f}(\mathrm{pD})$ for $\mathrm{P}$, $\mathrm{H}_{\mathrm{e}}$, and $\mathrm{H}_{6 / 8}$.

\section{Electrochemical studies of the $\mathrm{Cu}(\mathrm{II})$ complexes with ligand $\mathrm{L}_{2}$.}

In order to verify that the reduction potential of $\mathrm{CuL}_{2}$ is below the threshold for in vivo reduction, estimated to $-0.4 \mathrm{~V}$ (vs NHE), ${ }^{92,93}$ we performed cyclic voltammetry studies at different $\mathrm{pH}$ (Figure 8). 


\section{$\mathrm{Cu}(\mathrm{I}) \longrightarrow \mathrm{Cu}(\mathrm{II})$}

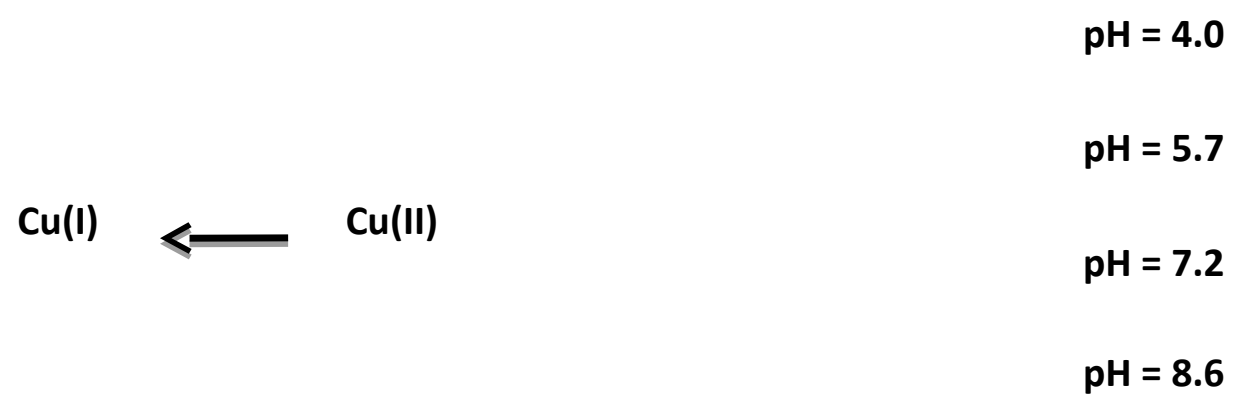

Figure 8. Cyclic voltammograms of $\mathrm{CuL}_{2}$ at different $\mathrm{pH}(V=200 \mathrm{mV} / \mathrm{s}) .\left[\mathrm{Cu} \mathbf{L}_{2}\right]=1.09 \times 10^{-3}$ $\mathrm{M}, \mathrm{H}_{2} \mathrm{O}, I=0.1 \mathrm{M}\left(\mathrm{NaClO}_{4}\right), T=25.0(2)^{\circ} \mathrm{C}$.

At physiological $\mathrm{pH}$ where the $\mathrm{Cu}_{2}$ species predominates, quasi-reversible processes were observed both in reduction and oxidation. A single redox couple was identified, corresponding to $\mathrm{Cu}(\mathrm{II}) / \mathrm{Cu}(\mathrm{I})\left(E_{\text {red }}=-0.81 \mathrm{~V}\right.$ vs $\mathrm{Ag} / \mathrm{AgCl}$ i.e. $E_{\text {red }}=-0.60 \mathrm{~V}$ vs $\left.\mathrm{NHE}\right)$, clearly indicating the absence of demetallation and suggesting that $\mathbf{L}_{2}$ is able to stabilize both $\mathrm{Cu}(\mathrm{II})$ and $\mathrm{Cu}(\mathrm{I})$ in this $\mathrm{pH}$ range. Similar behaviors were also observed for ligand $\mathbf{L}_{\mathbf{1}}$ and other bispidone derivatives ${ }^{21,4}$ and for NO1PA2PY $\left(E_{\text {red }}=-0.518 \mathrm{~V} v s \text { NHE }\right)^{44}$ and CB-TE1PA $\left(E_{1 / 2}=-0.62 v s\right.$ NHE $) .{ }^{94}$ Quasireversibility was also verified by measuring the peak anodic $\left(i_{\mathrm{pa}}\right)$ and cathodic $\left(i_{\mathrm{pc}}\right)$ currents with varying scan speed $(v)$ at fixed $\mathrm{pH}$. The linear plots of $i_{\mathrm{pa}}$ or $i_{\mathrm{pc}}=f\left(v^{1 / 2}\right)$ are shown in Figure S17. $\mathrm{E}_{\mathrm{red}}$ is similar to the value obtained for ligand $\mathbf{L}_{1}\left(E_{\mathrm{red}}=-0.56 \mathrm{~V}\right)$, and is well below the estimated $-0.40 \mathrm{~V}$ (vs NHE) threshold for typical bioreductants ${ }^{30}$ and below $\mathrm{Cu}(\mathrm{II})$ complexes with bispidones $\mathbf{L}_{0}\left(E_{\text {red }}=-0.323 \mathrm{~V} v s \mathrm{NHE}\right)$ and $\mathbf{H Z 2}\left(E_{\text {red }}=-0.225 \mathrm{~V}\right.$ vs NHE$) .{ }^{4}$ More stable 
bispidine ligands have been reported more recently, however, redox potentials were measured in organic solvents such as DMF $\left(E_{\text {red }}=-1.17 \mathrm{~V} v s\right.$ fc/fc + i.e. $E_{\text {red }}=-0.72 \mathrm{~V} v s$ NHE for $\left.\left[\mathrm{Cu}\left(\text { bispa }^{1 \mathrm{~b}}\right)\right]^{+}\right)$and acetonitrile $\left(E_{\mathrm{red}}=-0.66 \mathrm{~V} v s\right.$ fc/fc + i.e. $E_{\mathrm{red}}=-0.26 \mathrm{~V} v s$ NHE for $\left.[\mathrm{Cu}(\mathrm{N} 2 \mathrm{py} 4)]^{2+}\right)$ and therefore cannot be compared with our system. ${ }^{83}$ With such a low redox potential, the $\mathrm{CuL}_{2}$ complex should not be subject to reduction, demetallation, or dismutation under physiological conditions. Below $\mathrm{pH} 5$ and above $\mathrm{pH} 8.5$ more complex phenomena were observed (Figure S18 in accordance with the distribution curves showing the presence of other chemical species.

\section{Kinetic inertness of $\mathrm{CuL}_{2} \mathrm{H}_{2}$ in strongly Acidic Media.}

Good candidates for radiopharmaceutical applications exhibit strong stability at physiological $\mathrm{pH}$ and in reductive medium, good selectivity, but more importantly, high kinetic inertness toward dissociation..$^{95}$ The kinetic inertness of a complex is commonly evaluated by following its acidassisted dissociation in strongly acidic conditions under pseudo-first-order conditions. Providing all other criteria were satisfied, the obtained half-life was shown to be a good gauge of the in vivo stability of ${ }^{64} \mathrm{Cu}$-labeled chelates. ${ }^{96}$ The decomplexation of the $\mathrm{CuL}_{2} \mathrm{H}_{2}$ complex in $5 \mathrm{M}$ $\mathrm{HClO}_{4}$ aqueous solutions at $25{ }^{\circ} \mathrm{C}$ was followed by UV-visible absorption spectrophotometry both on the ligand $\pi-\pi^{*}$ transitions and the $\mathrm{Cu}(\mathrm{II}) \mathrm{d}-\mathrm{d}$ bands over a period of 20 months. Very minor decomplexation is observed within the period, as assessed by the slight decrease of the absorption spectrum of the d-d transitions (only $6.4 \%$ at $670 \mathrm{~nm}$, Figure S19), and which indicates a higher degree of inertness of the complex than the preciously studied $\mathrm{Cu}_{\mathbf{1}}\left(t_{1 / 2}=110\right.$ d) in the same conditions.

\section{Radiolabelling studies.}


The high stability of the $\mathrm{Cu}(\mathrm{II})$ complex prompted us to study the radiolabelling efficiency of ligand $\mathbf{L}_{2}$ with ${ }^{64} \mathrm{CuCl}_{2}$ in ammonium acetate buffer $0.1 \mathrm{M}$ at room temperature. ${ }^{64} \mathrm{Cu}$ sources of different specific activities and cold metal impurities were used. For each experiment, the total concentration in metals $([\mathrm{M}])$ of the batch used is taken into account. Two series of measurements were performed in order to optimize the radiolabelling conditions. On the one hand, the influence of the ligand/metal ratio was investigated at a fixed $\mathrm{pH}$ of 5.4 and on the other hand, the influence of the $\mathrm{pH}$ (i.e. $\mathrm{pH}=2$ to 7 ) was studied for a fixed $\mathrm{L} / \mathrm{M}$ ratio.

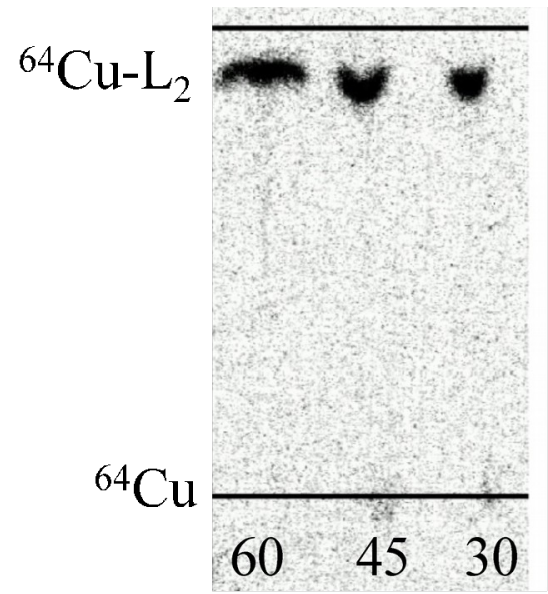

Figure 9. Thin layer radiochromatogram of ${ }^{64} \mathrm{Cu}-\mathbf{L}_{2}$ after $30 \mathrm{~min}, 45 \mathrm{~min}$ and 60 min reaction time at pH 5.4 at r.t. in $\mathrm{NH}_{4} \mathrm{OAc} 0.1 \mathrm{M}\left(\mathrm{SiO}_{2}\right.$, aq. $\left.\mathrm{NH}_{3} / \mathrm{MeOH} / \mathrm{H}_{2} \mathrm{O} 1 / 2 / 1\right)$. 


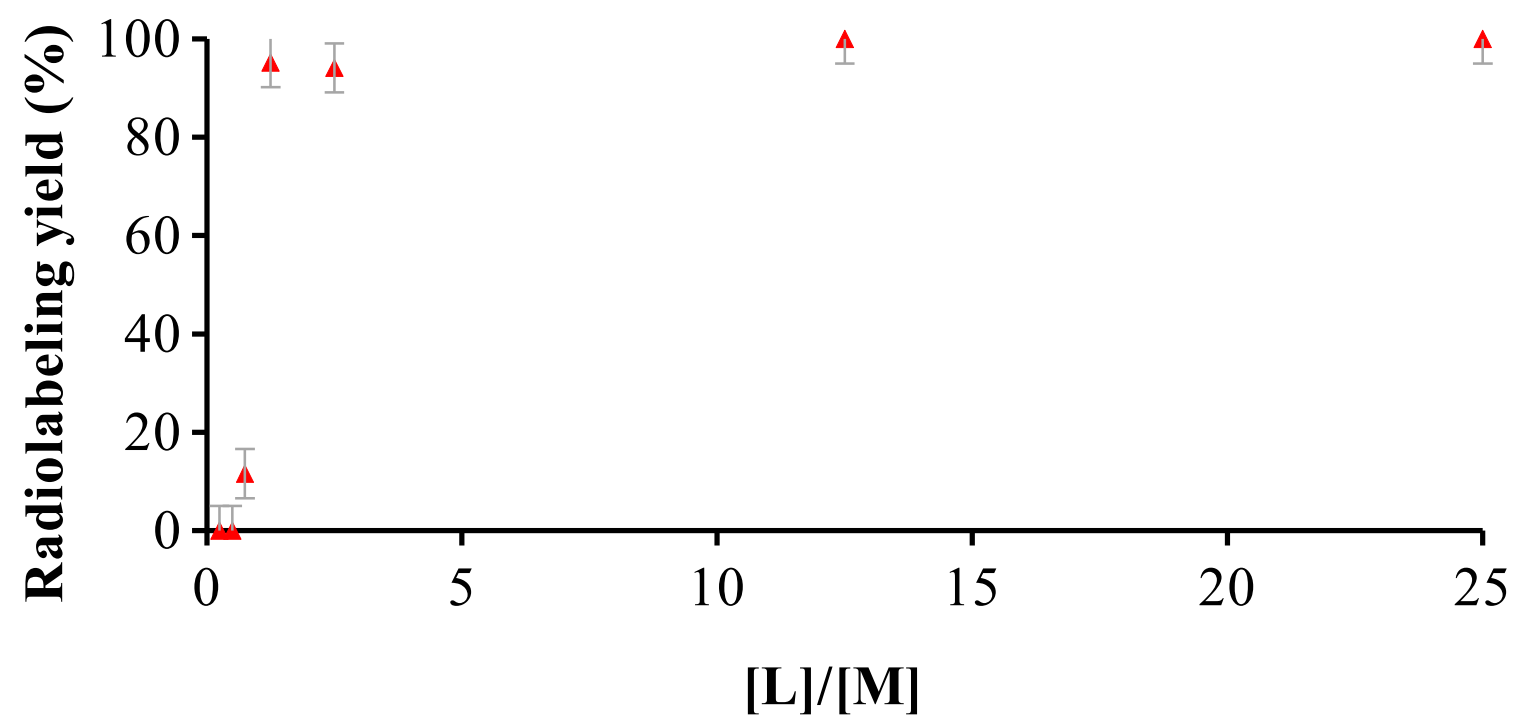

Figure 10. Radiolabelling yields of $\mathbf{L}_{2}(\mathbf{\Delta})$ at different ligand/metal ratios $\left(\mathrm{NH}_{4} \mathrm{OAc} 0.1 \mathrm{M} \mathrm{pH}\right.$ 5.4, r.t, $30 \mathrm{~min},{ }^{64} \mathrm{Cu}$ from batch $1,0.12 \mathrm{nmol} \leq \mathrm{n}$ (ligand) $\leq 12.0 \mathrm{nmol}, \mathrm{n}(\mathrm{Cu})=8.04 \mathrm{pmol}$.

\begin{tabular}{lcccccc}
\hline \multicolumn{7}{c}{$\mathrm{t}(\mathrm{min})$} \\
\hline $\mathbf{L} / \mathbf{M}$ & 5 & 10 & 15 & 30 & 45 & 60 \\
\hline $\mathbf{0 . 2 5}$ & 0 & 0 & 0 & 0 & 0 & 0 \\
$\mathbf{0 . 5}$ & 0 & 0 & 0 & 0 & 0 & 0 \\
$\mathbf{0 . 7 5}$ & 0 & 0 & 0 & 12 & 11 & 11 \\
$\mathbf{1 . 2 5}$ & $\geq 95^{*}$ & $\geq 95^{*}$ & $\geq 95^{*}$ & 95 & 96 & 94 \\
$\mathbf{2 . 5}$ & 92 & 93 & 93 & 94 & 92 & 100 \\
$\mathbf{1 2 . 5}$ & $\geq 95^{*}$ & $\geq 95^{*}$ & $\geq 95^{*}$ & 100 & 100 & 100 \\
$\mathbf{2 5}$ & 100 & 100 & 100 & 100 & 100 & 100 \\
\hline
\end{tabular}

Table 6. Time-dependence of the ${ }^{64} \mathrm{Cu}$ radiolabelling yields for $\mathbf{L}_{2}$ at different metal/ligand ratios $\left(\mathrm{NH}_{4} \mathrm{OAc} 0.1 \mathrm{M} \mathrm{pH} 5.4\right.$, r.t., ${ }^{64} \mathrm{Cu}$ from batch $1,0.12 \mathrm{nmol} \leq \mathrm{n}$ (ligand) $\leq 12.0 \mathrm{nmol}, \mathrm{n}(\mathrm{Cu})=8.04$ pmol). "No free $\mathrm{Cu}(\mathrm{II})$ was seen on radio-TLCs.

Quantitative radiolabelling was achieved for ligand $\mathbf{L}_{2}$ after $30 \mathrm{~min}$ at room temperature with $\mathrm{L} / \mathrm{M}$ ratios of 1.25 and above (Figure 9). In presence of sub-stoichiometric amount of ligand, radiolabelling did not occur at r.t. (Table 6). This might be explained by a slower kinetic of the 
radiolabelling reaction, due to the presence of competitive metal salts (in particular Fe(II/III) was present at a concentration of $6.38 \mathrm{ppm}$ in batch 1, which is relatively high for such production and purification processes). However, after incubation of the samples at $80^{\circ} \mathrm{C}$ for $1 \mathrm{~h}$, the ${ }^{64} \mathrm{Cu}-\mathbf{L}_{2}$ complex was formed in $4 \%, 5 \%$ and $22 \%$ yields for $\mathbf{L}_{2} / \mathbf{M}$ ratios of $0.25,0.5$ and 0.75 , respectively, at $80^{\circ} \mathrm{C}$, which indicate a thermodynamic selectivity of $\mathbf{L}_{2}$ for $\mathrm{Cu}(\mathrm{II})$ over the other cations. Moreover, very efficient radiolabelling (up to 95\%) was achieved within $30 \mathrm{~min}$ at room temperature and with $\mathbf{L}_{2} / \mathbf{M}$ ratios of only 1.25 . In presence of a larger excess of ligand (25 equivalents), quantitative radiolabelling was achieved within 5 minutes only. In similar conditions, the radiochemical yield of ligand $\mathbf{L}_{1}$ leveled at about $90 \%$. In the case of $\mathbf{L}_{4}$ and $\mathbf{L}_{5}$ (Chart 2), radiochemical yields of 95\% were obtained at room temperature in large excess of ligand $\left(10^{-4} \mathrm{M}\right)$. These results indicate a better radiolabelling capacity of the phosphonate derivative $\mathbf{L}_{2}$ over the carboxylate and the pyridyl analogues, which is partly explained by the stronger thermodynamic stability of the copper(II) complex with $\mathbf{L}_{2}$ (Table 6). 


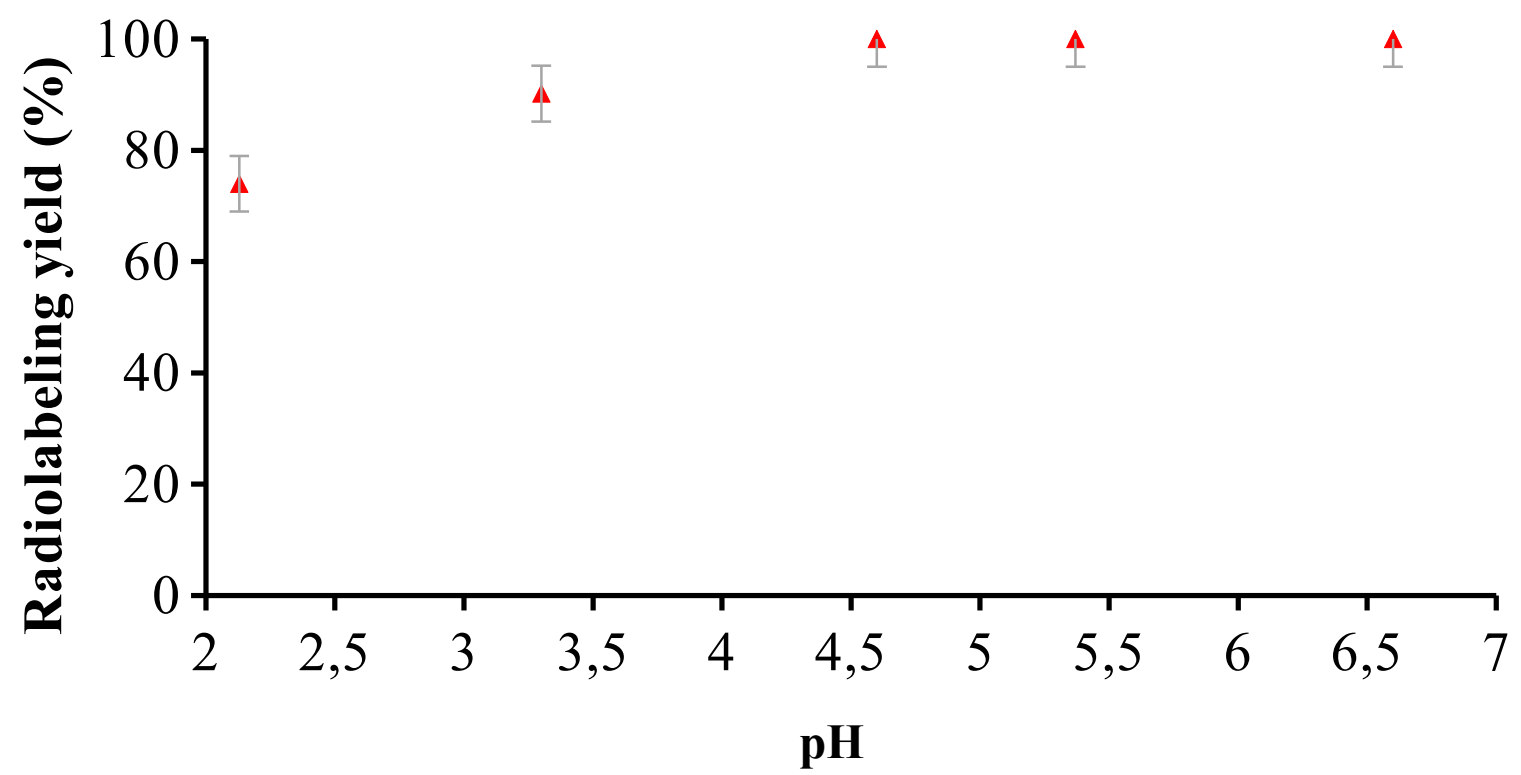

Figure 11. Radiolabelling yields of $\mathbf{L}_{2}(\mathbf{\Delta})$ at different $\mathrm{pH}$ values (r.t, $\mathrm{NH}_{4} \mathrm{OAc} 0.1 \mathrm{M}, 15 \mathrm{~min}$, ${ }^{64} \mathrm{Cu}$ from batch $1(\mathrm{pH} 2.1-4.6)$, n(ligand $)=0.6 \mathrm{~nm}, \mathrm{n}(\mathrm{Cu})=8.04 \mathrm{pmol}$, and from batch $2(\mathrm{pH}$ 4.6-6.6), $\mathrm{n}($ ligand $)=0.11 \mathrm{nmol}, \mathrm{n}(\mathrm{Cu})=22.4 \mathrm{pmol}, \mathrm{L} / \mathrm{M}=1.25$. "No free $\mathrm{Cu}(\mathrm{II})$ was seen on radio-TLCs. "No free $\mathrm{Cu}(\mathrm{II})$ was seen on radio-TLCs.

\begin{tabular}{llllllll}
\hline \multicolumn{7}{c}{$\mathrm{t}(\min )$} \\
\hline & $\mathbf{p H}$ & 5 & 10 & 15 & 30 & 45 & 60 \\
\hline $\mathbf{L}_{2}$ & $\mathbf{2 . 1}$ & 36 & 40 & 49 & 61 & 70 & 74 \\
& $\mathbf{3 . 3}$ & 60 & 70 & - & 87 & 89 & 90 \\
& $\mathbf{4 . 6}$ & $\geq 95^{*}$ & $\geq 95^{*}$ & $\geq 95^{*}$ & - & - & - \\
& $\mathbf{5 . 4}$ & $\geq 95^{*}$ & $\geq 95^{*}$ & $\geq 95^{*}$ & 95 & 96 & 94 \\
& $\mathbf{6 . 6}$ & $\geq 95^{*}$ & $\geq 95^{*}$ & $\geq 95^{*}$ & 100 & 100 & 100 \\
\hline
\end{tabular}

Table 7. Time-dependence of the radiolabelling yields of $\mathbf{L}_{2}$ at different $\mathrm{pH}$ values (r.t, $\mathrm{NH}_{4} \mathrm{OAc} 0.1 \mathrm{M},{ }^{64} \mathrm{Cu}$ from batch $1(\mathrm{pH} 2.1-4.6)$, n(ligand) $=0.6 \mathrm{~nm}, \mathrm{n}(\mathrm{Cu})=8.04 \mathrm{pmol}$, and from batch 2 (pH 4.6-6.6), $\mathrm{n}($ ligand $)=0.11 \mathrm{nmol}, \mathrm{n}(\mathrm{Cu})=22.4 \mathrm{pmol}, \mathrm{L} / \mathrm{M}=1.25)$.

The influence of the $\mathrm{pH}$ was also investigated in the range 2.1-6.6 (Table 7, Figure 11). Results indicate that $\mathrm{pH}$ control is mandatory for ligand $\mathbf{L}_{2}$, the reaction kinetic being significantly slower in acidic conditions, probably due to the competition with the protonated species $\mathbf{L}_{2} \mathrm{H}_{3}$, as 
emphasized by potentiometric and X-ray crystallographic data. However, above $\mathrm{pH} 5.4$, an efficient and quantitative radiolabelling was achieved at room temperature. With quantitative radiolabelling at ligand concentrations as low as $2 \times 10^{-7} \mathrm{M}$, we believe that $\mathbf{L}_{2}$ is a promising system for the complexation of ${ }^{64} \mathrm{Cu}$ and that it is worth investigating its in vivo behavior in further studies.

\section{Conclusion}

In conclusion, the phosphonate pendant-armed bispidol ligand $\mathbf{L}_{2}$ was easily synthesized in three steps from piperidinone and (aminomethyl)phosphonic acid. The evaluation of the physicochemical properties of the corresponding $\mathrm{Cu}(\mathrm{II})$ and $\mathrm{Zn}(\mathrm{II})$ complexes in water using $\mathrm{UV}$-visible absorption spectrophotometry, potentiometry, ${ }^{1} \mathrm{H}$ and ${ }^{31} \mathrm{P}$ NMR, cyclic voltammetry as well as radiolabelling experiments with ${ }^{64} \mathrm{Cu}(\mathrm{II})$ has been reported. Fast complexation of $\mathrm{Cu}(\mathrm{II})$ occurs in the 4.6-6.6 $\mathrm{pH}$ range and the complex demonstrates a strong thermodynamic stability (log $\beta_{\mathrm{CuL}} \mathbf{2}$ $=22.5, \mathrm{pCu}=19.1$ at $\mathrm{pH} 7.4)$, a good selectivity for $\mathrm{Cu}(\mathrm{II})$ vs. $\mathrm{Zn}(\mathrm{II})(\mathrm{pZn}=15.4$ at $\mathrm{pH} 7.4)$, as well as a very good kinetic inertness regarding reduction (with a reversible redox potential of $E_{\text {red }}$ $=-0.60 \mathrm{vs} \mathrm{NHE})$ and acid-assisted dissociation ( $t_{1 / 2}>>20$ months). Quantitative radiolabelling $(100 \% \pm 5 \%)$ was achieved within 5 minutes at room temperature at $\mathrm{pH}$ above 5.4 at ligand concentrations as low as $2 \times 10^{-7} \mathrm{M}$. From a coordination chemistry point of view, we believe that $\mathbf{L}_{2}$ meets all the required criteria to be used as new chelator for PET imaging with ${ }^{64} \mathrm{Cu}$. Although it is out of the scope of the present paper, in vitro and in vivo stability studies as well as biodistribution studies are still needed to validate the potential of $\mathbf{L}_{2}$ for ${ }^{64} \mathrm{Cu}$-immuno PET imaging. Several functionalization strategies are currently under study in order to obtain bifunctional ligands conjugated to antibodies. 


\section{ASSOCIATED CONTENT}

Supporting Information. 1D and 2D NMR spectra, plots of potentiometric titration data, plot showing the influence of scan speed on current intensity at $\mathrm{pH} 7.4$, cyclic voltammograms of $\mathrm{CuL}_{2}$ at various pHs, plot of the evolution of the absorption spectra of the d-d transition on $\mathrm{CuL}_{2} \mathrm{H}_{2}$ in $5 \mathrm{M} \mathrm{HClO}_{4}$ over 20 months at $25^{\circ} \mathrm{C}$ and crystallographic data for $2 \mathrm{Na}$ and $\mathrm{L}_{2}$ in $\mathrm{CIF}$ format. This material is available free of charge via the Internet at http://pubs.acs.org.

\section{AUTHOR INFORMATION}

\section{Corresponding Author}

*aline.nonat@unistra.fr, l.charbonn@unistra.fr. Give contact information for the author(s) to whom correspondence should be addressed.

\section{Author Contributions}

The manuscript was written through contributions of all authors. All authors have given approval to the final version of the manuscript.

\section{ACKNOWLEDGMENT}

This work was supported by the by the French Centre National de la Recherche Scientifique and the University of Strasbourg (UMR7178). The authors thank Mourad Elhabiri (Laboratoire de Chimie Médicinale et Bioorganique, UMR 7509 CNRS/UdS) for providing the facilities for cyclic voltammetry experiments as well as for thoughtful discussions. R. G. thanks the French Ministry of research and higher education for financial support for his PhD. The ARRONAX cyclotron is a project promoted by the Regional Council of Pays de la Loire, financed by local 
authorities, the French government and the European Union. This work has been, in part, supported by the French National Agency for Research ("Investissements d'Avenir” research grant Equipex Arronax-Plus no. ANR-11-EQPX-0004 and Labex no. ANR-11-LABX-0018-01) and Labex IRON.

\section{REFERENCES}

(1) Comba, P.; Kerscher, M.; Schiek, W. Bispidine Coordination Chemistry. In Progress in Inorganic Chemistry; Karlin, K. D., Ed.; John Wiley \& Sons, Inc., 2007; pp 613-704.

(2) Haller, R. Metal chelates of pyridyl-(2)-substituted 3,7-diaza-bicyclo-(3,3,1)-nonanones. Arch. Pharm. Ber. Dtsch. Pharm. Ges. 1969, 302 (2), 113-118.

(3) Börzel, H.; Comba, P.; Hagen, K. S.; Lampeka, Y. D.; Lienke, A.; Linti, G.; Merz, M.; Pritzkow, H.; Tsymbal, L. V. Iron Coordination Chemistry with Tetra-, Penta- and Hexadentate Bispidine-Type Ligands. Inorganica Chim. Acta 2002, 337, 407-419.

(4) Born, K.; Comba, P.; Ferrari, R.; Lawrance, G. A.; Wadepohl, H. Stability Constants: A New Twist in Transition Metal Bispidine Chemistry. Inorg. Chem. 2007, 46 (2), 458-464.

(5) Comba, P.; Kerscher, M.; Merz, M.; Müller, V.; Pritzkow, H.; Remenyi, R.; Schiek, W.; Xiong, Y. Structural Variation in Transition-Metal Bispidine Compounds. Chem. - Eur. J. 2002, 8 (24), 5750-5760.

(6) Bukowski, M. R.; Comba, P.; Lienke, A.; Limberg, C.; Lopez de Laorden, C.; MasBallesté, R.; Merz, M.; Que, L. Catalytic Epoxidation and 1,2-Dihydroxylation of Olefins with Bispidine-Iron(II)/ $\mathrm{H}_{2} \mathrm{O}_{2}$ Systems. Angew. Chem. Int. Ed. 2006, 45 (21), 3446-3449.

(7) Born, K.; Comba, P.; Daubinet, A.; Fuchs, A.; Wadepohl, H. Catecholase Activity of Dicopper(II)-Bispidine Complexes: Stabilities and Structures of Intermediates, Kinetics and Reaction Mechanism. JBIC J. Biol. Inorg. Chem. 2007, 12 (1), 36-48.

(8) Comba, P.; Haaf, C.; Lienke, A.; Muruganantham, A.; Wadepohl, H. Synthesis, Structure, and Highly Efficient Copper-Catalyzed Aziridination with a Tetraaza-Bispidine Ligand. Chem. - Eur. J. 2009, 15 (41), 10880-10887.

(9) Zayya, A. I.; Spencer, J. L. Coordination Chemistry of a Bicyclic 3-Aza-7Phosphabicyclo[3.3.1]-Nonan-9-One Ligand. Organometallics 2012, 31 (7), 2841-2853. 
(10) Scharnagel, D.; Müller, A.; Prause, F.; Eck, M.; Goller, J.; Milius, W.; Breuning, M. The First Modular Route to Core-Chiral Bispidine Ligands and Their Application in Enantioselective Copper(II)-Catalyzed Henry Reactions. Chem. - Eur. J. 2015, 21 (35), 12488-12500.

(11) Barman, P.; Vardhaman, A. K.; Martin, B.; Wörner, S. J.; Sastri, C. V.; Comba, P. Influence of Ligand Architecture on Oxidation Reactions by High-Valent Nonheme Manganese Oxo Complexes Using Water as a Source of Oxygen. Angew. Chem. Int. Ed. 2015, 54 (7), 2095-2099.

(12) Ang, W. J.; Chng, Y. S.; Lam, Y. Fluorous Bispidine: A Bifunctional Reagent for CopperCatalyzed Oxidation and Knoevenagel Condensation Reactions in Water. RSC Adv. 2015, 5 (99), 81415-81428.

(13) Bautz, J.; Comba, P.; Que, L. Spin-Crossover in an Iron(III)-Bispidine-Alkylperoxide System. Inorg. Chem. 2006, 45 (18), 7077-7082.

(14) Atanasov, M.; Busche, C.; Comba, P.; El Hallak, F.; Martin, B.; Rajaraman, G.; van Slageren, J.; Wadepohl, H. Trinuclear $\{$ M1 $\}$ CN $\{$ M2 22 Complexes (M1 = CrIII, FeIII, CoIII; M2 = CuII, NiII, MnII). Are Single Molecule Magnets Predictable? Inorg. Chem. 2008, 47 (18), 8112-8125.

(15) Atanasov, M.; Comba, P.; Helmle, S. Cyanide-Bridged FeIII-CuII Complexes: Jahn-Teller Isomerism and Its Influence on the Magnetic Properties. Inorg. Chem. 2012, 51 (17), 9357-9368.

(16) Kolanowski, J. L.; Jeanneau, E.; Steinhoff, R.; Hasserodt, J. Bispidine Platform Grants Full Control over Magnetic State of Ferrous Chelates in Water. Chem. - Eur. J. 2013, 19 (27), 8839-8849.

(17) Comba, P.; Rudolf, H.; Wadepohl, H. Synthesis and Transition Metal Coordination Chemistry of a Novel Hexadentate Bispidine Ligand. Dalton Trans. 2015, 44 (6), 27242736.

(18) Juran, S.; Walther, M.; Stephan, H.; Bergmann, R.; Steinbach, J.; Kraus, W.; Emmerling, F.; Comba, P. Hexadentate Bispidine Derivatives as Versatile Bifunctional Chelate Agents for Copper(II) Radioisotopes. Bioconjug. Chem. 2009, 20 (2), 347-359. 
(19) Comba, P.; Hunoldt, S.; Morgen, M.; Pietzsch, J.; Stephan, H.; Wadepohl, H. Optimization of Pentadentate Bispidines as Bifunctional Chelators for ${ }^{64} \mathrm{Cu}$ Positron Emission Tomography (PET). Inorg. Chem. 2013, 52 (14), 8131-8143.

(20) Comba, P.; Kubeil, M.; Pietzsch, J.; Rudolf, H.; Stephan, H.; Zarschler, K. Bispidine Dioxotetraaza Macrocycles: A New Class of Bispidines for 64Cu PET Imaging. Inorg. Chem. 2014, 53 (13), 6698-6707.

(21) Roux, A.; Nonat, A. M.; Brandel, J.; Hubscher-Bruder, V.; Charbonnière, L. J. Kinetically Inert Bispidol-Based $\mathrm{Cu}(\mathrm{II})$ Chelate for Potential Application to 64/67Cu Nuclear Medicine and Diagnosis. Inorg. Chem. 2015, 54 (9), 4431-4444.

(22) Brasse, D.; Nonat, A. Radiometals: Towards a New Success Story in Nuclear Imaging? Dalton Trans. 2015, 44 (11), 4845-4858.

(23) Adumeau, P.; Sharma, S. K.; Brent, C.; Zeglis, B. M. Site-Specifically Labeled Immunoconjugates for Molecular Imaging-Part 1: Cysteine Residues and Glycans. Mol. Imaging Biol. 2016, 18 (1), 1-17.

(24) Adumeau, P.; Sharma, S. K.; Brent, C.; Zeglis, B. M. Site-Specifically Labeled Immunoconjugates for Molecular Imaging-Part 2: Peptide Tags and Unnatural Amino Acids. Mol. Imaging Biol. 2016, 18 (2), 153-165.

(25) England, C. G.; Hernandez, R.; Eddine, S. B. Z.; Cai, W. Molecular Imaging of Pancreatic Cancer with Antibodies. Mol. Pharm. 2016, 13 (1), 8-24.

(26) Sehlin, D.; Fang, X. T.; Cato, L.; Antoni, G.; Lannfelt, L.; Syvänen, S. Antibody-Based PET Imaging of Amyloid Beta in Mouse Models of Alzheimer's Disease. Nat. Commun. 2016, 7, 10759.

(27) Wu, A. M. Antibodies and Antimatter: The Resurgence of Immuno-PET. J. Nucl. Med. 2009, 50 (1), 2-5.

(28) Steiner, M.; Neri, D. Antibody-Radionuclide Conjugates for Cancer Therapy: Historical Considerations and New Trends. Am. Assoc. Cancer Res. 2011, 17 (20), 6406-6416.

(29) Kaur, S.; Venktaraman, G.; Jain, M.; Senapati, S.; Garg, P. K.; Batra, S. K. Recent Trends in Antibody-Based Oncologic Imaging. Cancer Lett. 2012, 315 (2), 97-111.

(30) Wadas, T. J.; Wong, E. H.; Weisman, G. R.; Anderson, C. J. Coordinating Radiometals of Copper, Gallium, Indium, Yttrium, and Zirconium for PET and SPECT Imaging of Disease. Chem. Rev. 2010, 110 (5), 2858-2902. 
(31) Shokeen, M.; Anderson, C. J. Molecular Imaging of Cancer with Copper-64 Radiopharmaceuticals and Positron Emission Tomography (PET). Acc. Chem. Res. 2009, 42 (7), 832-841.

(32) Price, E. W.; Orvig, C. Matching Chelators to Radiometals for Radiopharmaceuticals. Chem. Soc. Rev. 2013, 43 (1), 260-290.

(33) Price, T. W.; Greenman, J.; Stasiuk, G. J. Current Advances in Ligand Design for Inorganic Positron Emission Tomography Tracers Ga-68, Cu-64, Zr-89 and Sc-44. Dalton Trans. 2016, 45 (40), 15702-15724.

(34) Bandara, N.; Sharma, A. K.; Krieger, S.; Schultz, J. W.; Han, B. H.; Rogers, B. E.; Mirica, L. M. Evaluation of ${ }^{64} \mathrm{Cu}$-Based Radiopharmaceuticals That Target A $\beta$ Peptide Aggregates as Diagnostic Tools for Alzheimer's Disease. J. Am. Chem. Soc. 2017.

(35) Cooper, M. S.; Ma, M. T.; Sunassee, K.; Shaw, K. P.; Williams, J. D.; Paul, R. L.; Donnelly, P. S.; Blower, P. J. Comparison of ${ }^{64} \mathrm{Cu}$-Complexing Bifunctional Chelators for Radioimmunoconjugation: Labeling Efficiency, Specific Activity, and in Vitro/in Vivo Stability. Bioconjug. Chem. 2012, 23 (5), 1029-1039.

(36) Zhang, Y.; Hong, H.; Engle, J. W.; Bean, J.; Yang, Y.; Leigh, B. R.; Barnhart, T. E.; Cai, W. Positron Emission Tomography Imaging of CD105 Expression with a 64 Cu-Labeled Monoclonal Antibody: NOTA Is Superior to DOTA. PLOS ONE 2011, 6 (12), e28005.

(37) Anderson, C. J.; Dehdashti, F.; Cutler, P. D.; Schwarz, S. W.; Laforest, R.; Bass, L. A.; Lewis, J. S.; McCarthy, D. W. ${ }^{64} \mathrm{Cu}$-TETA-Octreotide as a PET Imaging Agent for Patients with Neuroendocrine Tumors. J. Nucl. Med. 2001, 42 (2), 213-221.

(38) Pandya, D. N.; Kim, J. Y.; Park, J. C.; Lee, H.; Phapale, P. B.; Kwak, W.; Choi, T. H.; Cheon, G. J.; Yoon, Y.-R.; Yoo, J. Revival of TE2A; a Better Chelate for Cu(II) Ions than TETA? Chem. Commun. 2010, 46 (20), 3517-3519.

(39) Pandya, D. N.; Bhatt, N.; Dale, A. V.; Kim, J. Y.; Lee, H.; Ha, Y. S.; Lee, J.-E.; An, G. I.; Yoo, J. New Bifunctional Chelator for 64Cu-Immuno-Positron Emission Tomography. Bioconjug. Chem. 2013, 24 (8), 1356-1366.

(40) Lima, L. M. P.; Esteban-Gómez, D.; Delgado, R.; Platas-Iglesias, C.; Tripier, R. Monopicolinate Cyclen and Cyclam Derivatives for Stable Copper(II) Complexation. Inorg. Chem. 2012, 51 (12), 6916-6927. 
(41) Frindel, M.; Camus, N.; Rauscher, A.; Bourgeois, M.; Alliot, C.; Barré, L.; Gestin, J.-F.; Tripier, R.; Faivre-Chauvet, A. Radiolabeling of HTE1PA: A New Monopicolinate Cyclam Derivative for Cu-64 Phenotypic Imaging. In Vitro and in Vivo Stability Studies in Mice. Nucl. Med. Biol. 2014, 41, e49-e57.

(42) Frindel, M.; Camus, N.; Rauscher, A.; Bourgeois, M.; Alliot, C.; Barre, L.; Gestin, J.-F.; Tripier, R.; Faivre-Chauvet, A. Radiolabeling of HTE1PA: A New Monopicolinate Cyclam Derivative for Cu-64 Phenotypic Imaging. In Vitro and in Vivo Stability Studies in Mice. Nucl. Med. Biol. 2014, 41 Suppl, e49-57.

(43) Frindel, M.; Le Saëc, P.; Beyler, M.; Navarro, A.-S.; Saï-Maurel, C.; Alliot, C.; Chérel, M.;

Gestin, J.-F.; Faivre-Chauvet, A.; Tripier, R. Cyclam Te1pa for ${ }^{64} \mathrm{Cu}$ PET Imaging. Bioconjugation to Antibody, Radiolabeling and Preclinical Application in Xenografted Colorectal Cancer. RSC Adv 2017, 7 (15), 9272-9283.

(44) Roger, M.; Lima, L. M. P.; Frindel, M.; Platas-Iglesias, C.; Gestin, J.-F.; Delgado, R.; Patinec, V.; Tripier, R. Monopicolinate-Dipicolyl Derivative of Triazacyclononane for Stable Complexation of $\mathrm{Cu}^{2+}$ and ${ }^{64} \mathrm{Cu}^{2+}$. Inorg. Chem. 2013, 52 (9), 5246-5259.

(45) Guillou, A.; Lima, L. M. P.; Roger, M.; Esteban-Gòmez, D.; Delgado, R.; Platas-Iglesias, C.; Patinec, V.; Tripier, R. 1,4,7-Triazacyclononane-Based Bifunctional Picolinate Ligands for Efficient Copper Complexation: 1,4,7-Triazacyclononane-Based Bifunctional Picolinate Ligands for Efficient Copper Complexation. Eur. J. Inorg. Chem. 2017, 2017 (18), 2435-2443.

(46) Boros, E.; Rybak-Akimova, E.; Holland, J. P.; Rietz, T.; Rotile, N.; Blasi, F.; Day, H.; Latifi, R.; Caravan, P. Pycup? A Bifunctional, Cage-like Ligand for ${ }^{64} \mathrm{Cu}$ Radiolabeling. Mol. Pharm. 2014, 11 (2), 617-629.

(47) Wadas, T. J.; Anderson, C. J. Radiolabeling of TETA- and CB-TE2A-Conjugated Peptides with Copper-64. Nat. Protoc. 2007, 1 (6), 3062-3068.

(48) Esteves, C. V.; Lamosa, P.; Delgado, R.; Costa, J.; Désogère, P.; Rousselin, Y.; Goze, C.; Denat, F. Remarkable Inertness of Copper(II) Chelates of Cyclen-Based Macrobicycles with Two Trans - N -Acetate Arms. Inorg. Chem. 2013, 52 (9), 5138-5153.

(49) Ferdani, R.; Stigers, D. J.; Fiamengo, A. L.; Wei, L.; Li, B. T. Y.; Golen, J. A.; Rheingold, A. L.; Weisman, G. R.; Wong, E. H.; Anderson, C. J. Synthesis, Cu(II) Complexation, 
${ }^{64} \mathrm{Cu}$-Labeling and Biological Evaluation of Cross-Bridged Cyclam Chelators with Phosphonate Pendant Arms. Dalton Trans. 2012, 41 (7), 1938-1950. Derivative CB-TE1K1P, an Improved Bifunctional Chelator for Copper Radionuclides. Chem. Commun. 2013, 50 (1), 43-45.

(51) Dale, A. V.; An, G. I.; Pandya, D. N.; Ha, Y. S.; Bhatt, N.; Soni, N.; Lee, H.; Ahn, H.; Sarkar, S.; Lee, W.; Huynh, P. T.; Kim, J. Y.; Gwon, M.-R.; Kim, S. H.; Park, J. G.; Yoon, Y.-R.; Yoo, J. Synthesis and Evaluation of New Generation Cross-Bridged Bifunctional Chelator for 64Cu Radiotracers. Inorg. Chem. 2015, 54 (17), 8177-8186.

Bhatt, N.; Soni, N.; Ha, Y. S.; Lee, W.; Pandya, D. N.; Sarkar, S.; Kim, J. Y.; Lee, H.; Kim, S. H.; An, G. I.; Yoo, J. Phosphonate Pendant Armed Propylene Cross-Bridged Cyclam: Synthesis and Evaluation as a Chelator for Cu-64. Acs Med. Chem. Lett. 2015, 6 (11), 1162-1166.

(53) Boros, E.; Cawthray, J. F.; Ferreira, C. L.; Patrick, B. O.; Adam, M. J.; Orvig, C. Evaluation of the H2dedpa Scaffold and Its CRGDyK Conjugates for Labeling with 64Cu. Inorg. Chem. 2012, 51 (11), 6279-6284.

(54) Ramogida, C. F.; Boros, E.; Patrick, B. O.; Zeisler, S. K.; Kumlin, J.; Adam, M. J.; Schaffer, P.; Orvig, C. Evaluation of $\mathrm{H}_{2} \mathrm{CHXdedpa}, \mathrm{H}_{2}$ Dedpa- and $\mathrm{H}_{2} \mathrm{CHXdedpa-N,N^{ \prime } -}$ Propyl-2-NI Ligands for ${ }^{64} \mathrm{Cu}(\mathrm{II})$ Radiopharmaceuticals. Dalton Trans 2016, 45 (33), 13082-13090.

(55) Di Bartolo, N.; Sargeson, A. M.; Smith, S. V. New Cu-64 PET Imaging Agents for Personalised Medicine and Drug Development Using the Hexa-Aza Cage, SarAr. Org. Biomol. Chem. 2006, 4 (17), 3350-3357.

(56) Paterson, B. M.; Buncic, G.; McInnes, L. E.; Roselt, P.; Cullinane, C.; Binns, D. S.; Jeffery, C. M.; Price, R. I.; Hicks, R. J.; Donnelly, P. S. Bifunctional ${ }^{64} \mathrm{Cu}$-Labelled Macrobicyclic Cage Amine Isothiocyanates for Immuno-Positron Emission Tomography. Dalton Trans. 2015, 44 (11), 4901-4909.

(57) Bartolo, N. M. D.; Sargeson, A. M.; Donlevy, T. M.; Smith, S. V. Synthesis of a New Cage Ligand, SarAr, and Its Complexation with Selected Transition Metal Ions for Potential Use in Radioimaging. J. Chem. Soc. Dalton Trans. 2001, No. 15, 2303-2309. 
(58) Roux, A.; Gillet, R.; Huclier-Markai, S.; Ehret-Sabatier, L.; Charbonnière, L. J.; Nonat, A. M. Bifunctional Bispidine Derivatives for Copper-64 Labelling and Positron Emission Tomography. Org. Biomol. Chem. 2017, 15 (6), 1475-1483.

(59) Lukeš, I.; Kotek, J.; Vojtišek, P.; Hermann, P. Complexes of Tetraazacycles Bearing Methylphosphinic/Phosphonic Acid Pendant Arms with Copper(II), Zinc(II) and Lanthanides(III). A Comparison with Their Acetic Acid Analogues. Coord. Chem. Rev. 2001, 216-217, 287-312.

(60) Abada, S.; Lecointre, A.; Déchamps-Olivier, I.; Platas-Iglesias, C.; Christine, C.; Elhabiri, M.; Charbonniere, L. Highly Stable Acyclic Bifunctional Chelator for ${ }^{64} \mathrm{Cu}$ PET Imaging. Radiochim. Acta 2011, 99 (10), 663-678.

(61) Abada, S.; Lecointre, A.; Christine, C.; Ehret-Sabatier, L.; Saupe, F.; Orend, G.; Brasse, D.; Ouadi, A.; Hussenet, T.; Laquerrière, P.; Elhabiri, M.; Charbonnière, L. J. Phosphonated Chelates for Nuclear Imaging. Org. Biomol. Chem. 2014, 12 (47), 96019620 .

(62) Abada, S.; Lecointre, A.; Elhabiri, M.; Charbonnière, L. J. Formation of Very Stable and Selective $\mathrm{Cu}(\mathrm{II})$ Complexes with a Non-Macrocyclic Ligand: Can Basicity Rival PreOrganization? Dalton Trans. 2010, 39 (38), 9055-9062.

(63) Ferreira, C. L.; Yapp, D. T.; Lamsa, E.; Gleave, M.; Bensimon, C.; Jurek, P.; Kiefer, G. E. Evaluation of Novel Bifunctional Chelates for the Development of Cu-64-Based Radiopharmaceuticals. Nucl. Med. Biol. 2008, 35 (8), 875-882.

(64) Bevilacqua, A.; Gelb, R. I.; Hebard, W. B.; Zompa, L. J. Equilibrium and Thermodynamic Study of the Aqueous Complexation of 1,4,7-Triazacyclononane-N,N',N'”-Triacetic Acid with Protons, Alkaline-Earth-Metal Cations, and Copper(II). Inorg. Chem. 1987, 26 (16), 2699-2706.

(65) Bailey, G. A.; Price, E. W.; Zeglis, B. M.; Ferreira, C. L.; Boros, E.; Lacasse, M. J.; Patrick, B. O.; Lewis, J. S.; Adam, M. J.; Orvig, C. H2azapa: A Versatile Acyclic Multifunctional Chelator for ${ }^{67} \mathrm{Ga},{ }^{64} \mathrm{Cu},{ }^{111} \mathrm{In}$, and ${ }^{177} \mathrm{Lu}$. Inorg. Chem. 2012, 51 (22), 12575-12589.

(66) Gottlieb, H. E.; Kotlyar, V.; Nudelman, A. NMR Chemical Shifts of Common Laboratory Solvents as Trace Impurities. J. Org. Chem. 1997, 62 (21), 7512-7515. 
(67) Mikkelsen, K.; Nielsen, S. O. Acidity Measurements with the Glass Electrode in $\mathrm{H}_{2} \mathrm{O}-\mathrm{D}_{2} \mathrm{O}$ Mixtures. J. Phys. Chem. 1960, 64 (5), 632-637.

(68) Patiny, L.; Borel, A. ChemCalc: A Building Block for Tomorrow's Chemical Infrastructure. J. Chem. Inf. Model. 2013, 53 (5), 1223-1228.

(69) Altomare, A.; Burla, M. C.; Camalli, M.; Cascarano, G. L.; Giacovazzo, C.; Guagliardi, A.; Moliterni, A. G. G.; Polidori, G.; Spagna, R. SIR97: A New Tool for Crystal Structure Determination and Refinement. J. Appl. Crystallogr. 1999, 32, 115-119.

(70) Sheldrick, G. M. A Short History of SHELX. Acta Crystallogr. Sect. A 2008, 64, 112-122.

(71) Farrugia, L. J. WinGX Suite for Small-Molecule Single-Crystal Crystallography. J. Appl. Cryst. 1999, pp 837-839.

(72) Legdali, T.; Roux, A.; Platas-Iglesias, C.; Camerel, F.; Nonat, A. M.; Charbonnière, L. J. Substitution-Assisted Stereochemical Control of Bispidone-Based Ligands. J. Org. Chem. 2012, 77 (24), 11167-11176.

(73) Szczepaniak, W.; Kuczynski, K. New Preparative Method for Aminomethylphosphonic, Aminoisopropylphosphonic and Iminobis(Methylenephosphonic) Acids. Phosphorus and Sulfur and the Related Elements. 1979, pp 333-337.

(74) Méthodes d'analyse complexométriques avec les titriplex; Merck E: Darmstadt, 1990.

(75) Raymond, K. Tragic Consequence with Acetonitrile Adduct. Chem. Eng. News 1983, 61 (49), 4-4.

(76) Gans, P.; O’Sullivan, B. GLEE@); Protonic Softwares: Leeds, UK and Berkeley, CA, 2005.

(77) Gans, P.; O’Sullivan, B. GLEE, a New Computer Program for Glass Electrode Calibration. Talanta 2000, 51 (1), 33-37.

(78) Gans, P.; Sabatini, A.; Vacca, A. Investigation of Equilibria in Solution. Determination of Equilibrium Constants with the HYPERQUAD Suite of Programs. Talanta 1996, 43 (10), 1739-1753.

(79) Alderighi, L.; Gans, P.; Ienco, A.; Peters, D.; Sabatini, A.; Vacca, A. Hyperquad Simulation and Speciation (HySS): A Utility Program for the Investigation of Equilibria Involving Soluble and Partially Soluble Species. Coord. Chem. Rev. 1999, 184, 311-318.

(80) Gampp, H.; Maeder, M.; Meyer, C.; Zuberbuhler, A. Calculation of Equilibrium-Constants from Multiwavelength Spectroscopic Data .1. Mathematical Considerations. Talanta 1985, 32 (2), 95-101. 
(81) Cyrille Alliot; Michel, N.; Bonraisin, A.-C.; Bossé, V.; Laizé, J.; Bourdeau, C.; Mokili, B. M.; Haddad, F. One Step Purification Process for No-Carrier-Added ${ }^{64} \mathrm{Cu}$ Produced Using Enriched Nickel Target. Radiochimica Acta. 99th ed. 2011, pp 627-630.

(82) Bleiholder, C.; Börzel, H.; Comba, P.; Ferrari, R.; Heydt, M.; Kerscher, M.; Kuwata, S.; Laurenczy, G.; Lawrance, G. A.; Lienke, A.; Martin, B.; Merz, M.; Nuber, B.; Pritzkow, H. Coordination Chemistry of a New Rigid, Hexadentate Bispidine-Based Bis(Amine)Tetrakis(Pyridine) Ligand. Inorg. Chem. 2005, 44 (22), 8145-8155.

(83) Comba, P.; Grimm, L.; Orvig, C.; Rück, K.; Wadepohl, H. Synthesis and Coordination Chemistry of Hexadentate Picolinic Acid Based Bispidine Ligands. Inorg. Chem. 2016, 55 (24), 12531-12543.

(84) Meyer, M.; Frémond, L.; Tabard, A.; Espinosa, E.; Vollmer, G. Y.; Guilard, R.; Dory, Y. Synthesis, Characterization and X-Ray Crystal Structures of Cyclam Derivatives. Part VI. Proton Binding Studies of a Pyridine-Strapped 5,12-Dioxocyclam Based Macrobicycle. New J. Chem. 2005, 29 (1), 99-108.

(85) Gans, P.; Sabatini, A.; Vacca, A. HYPERQUAD2000; Protonic Software, Leeds, U.K. and University of Florence, Italy, 2000.

(86) Siener, T.; Cambareri, A.; Kuhl, U.; Englberger, W.; Haurand, M.; Kögel, B.; Holzgrabe, U. Synthesis and Opioid Receptor Affinity of a Series of 2, 4-Diaryl-Substituted 3,7Diazabicylononanones. J. Med. Chem. 2000, 43 (20), 3746-3751.

(87) Kuhl, U.; Englberger, W.; Haurand, M.; Holzgrabe, U. Diazabicyclo[3.3.1]Nonanone-Type Ligands for the Opioid Receptors. Arch. Pharm. Pharm. Med. Chem. 2000, pp 226-230.

(88) Hosken, G. D.; Hancock, R. D. Very Strong and Selective Complexation of Small Metal Lons by a Highly Preorganised Open-Chain Bispidine-Based Ligand. J. Chem. Soc. Chem. Commun. 1994, No. 11, 1363-1364.

(89) Lomozik, L. Monatsh. Chem. 1984, pp 261-270.

(90) Hathaway, B. J.; Billing, D. E. The Electronic Properties and Stereochemistry of MonoNuclear Complexes of the Copper(II) Ion. Coord. Chem. Rev. 1970, 5 (2), 143-207.

(91) Patel, R. N.; Shrivastava, R. P.; Singh, N.; Kumar, S.; Pandeya, K. B. Equilibrium Studies on Mixed-Ligand Mixed-Metal Complexes of Copper(II), Nickel(II) and Zinc(II) with Glycylvaline and Imidazole. Indian Journal of Chemistry. 2001, pp 361-367. 
(92) Clark, W. M. Oxidation-Reduction Potentials of Organic Systems. In Encyclopedia of Electrochemistry of the Elements; New York, 1976.

(93) Krebs, H. A.; Kornberg, H. L.; Burton, K. Energy Transformations in Living Matter: A Survey, Springer.; 1957.

(94) Lima, L. M. P.; Halime, Z.; Marion, R.; Camus, N.; Delgado, R.; Platas-Iglesias, C.; Tripier, R. Monopicolinate Cross-Bridged Cyclam Combining Very Fast Complexation with Very High Stability and Inertness of Its Copper(II) Complex. Inorg. Chem. 2014, 53 (10), 5269-5279.

(95) Woodin, K. S.; Heroux, K. J.; Boswell, C. A.; Wong, E. H.; Weisman, G. R.; Niu, W.; Tomellini, S. A.; Anderson, C. J.; Zakharov, L. N.; Rheingold, A. L. Kinetic Inertness and Electrochemical Behavior of Copper(II) Tetraazamacrocyclic Complexes: Possible Implications for in Vivo Stability. Eur. J. Inorg. Chem. 2005, 2005 (23), 4829-4833.

(96) Odendaal, A. Y.; Fiamengo, A. L.; Ferdani, R.; Wadas, T. J.; Hill, D. C.; Peng, Y.; Heroux, K. J.; Golen, J. A.; Rheingold, A. L.; Anderson, C. J.; Weisman, G. R.; Wong, E. H. Isomeric Trimethylene and Ethylene Pendant-Armed Cross-Bridged Tetraazamacrocycles and in Vitro/in Vivo Comparisions of Their Copper(II) Complexes. Inorg. Chem. 2011, 50 (7), 3078-3086. 


\section{Synopsis - For Table of Content Only}

A new hexadentate bispidol ligand with a pendant phosphonate group has been synthesized to be used for PET imaging. This ligand forms highly stable $\mathrm{Cu}(\mathrm{II})$ complexes with high kinetic inertness regarding reduction and acid-assisted dissociation. Quantitative radiolabelling was achieved within $5 \mathrm{~min}$ at room temperature at $\mathrm{pH} 4.6$ and above and at submicromolar concentrations of ligand.
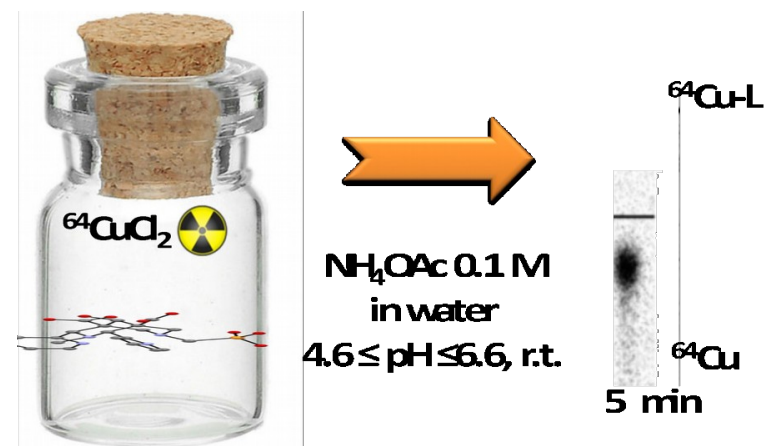